\title{
Landscapes of the Social Relations of Production in a Networked Society
}

\author{
Robert Goldman, Stephen Papson, Noah Kersey
}

\begin{abstract}
Thus the social relations within which individuals produce, the social relations of production, change, are transformed, with the change and development of the material means of production, the productive forces. The relations of production in their totality constitute what are called the social relations, society, and specifically, a society at a definite stage of historical development, a society with a peculiar and distinctive character (Marx "Wage Labor and Capital" 1849: 207).
\end{abstract}

Each stage of capitalist society constitutes such a totality of relations, subject to a dialectic of historical change in which developments in the material means of production prompt transformations of social relations, and vice versa. These social relations of production "in their totality" include the work relations affected by division of labor, technology, and organizational technique. Such arrangements have historically been stratified by race, gender, age and ethnicity. Another fundamental dimension of capitalist society encompasses the structures imposed by market forces and commodity relations. The formal-legal relations of property ownership and contracts define rights of access to productive resources as well as defining how the surplus is appropriated and by whom. And, the wider relations of production encompass those who are not directly in the labor force - children, retirees, and those who help reproduce the conditions of everyday life (e.g., unpaid housework). People's social relationships and their ideas about themselves, about nature and the social world may be understood in relation to the ways productive and reproductive activity is organized.

The social relations of production in a capitalist society are complex, contradictory, conflictual and unequal. Property relations, work relations and market relations yield not just stratification patterns but the deeper patterns that govern appropriation of surplus and class relations. It might seem odd then to envision the social relations of production - the deep underlying structural forces - through the lens of advertising. After all, ads are all about superficiality. They celebrate the sponsoring corporation, place a halo around its representation, gloss social relations, and repress as much as possible what is negative, conflictual, complex or unequal about the corporate political economy. Advertising works as an extension of public relations discourse and thus situates the unfettered corporation as the prime movers of technological, economic, social and political progress.

Advertising might be superficial and intentionally one-sided, but it is not entirely stagnant. In order to connect with its potential audiences, ads also carry within their discursive frames hints of important transformations that may be taking place with the transition to global systems of production. Because Capital is not monolithic, but constituted by competing interests, agendas and discourses, advertising does not present a unitary vision of society. We would expect nothing less in a competitive capitalist system. Hence while advertisers might say nothing negative about their own brand that does not prevent them from denigrating competitors' services or products. To diminish the brand value of competitors, advertisers may address problematic aspects of the social relations of production by making jokes about them. We have written extensively of "sign wars" or "brand wars" wherein advertisers do battle with signs and symbols in search of brand dominance. Ironically, in this domain of sign competitions where initially it seemed as if all concern with how goods and services are actually produced, distributed and consumed had vanished, the ghostly spectre of the social relations of production reappears.

Ads compose stylized spatial landscapes of the relations of production, while sometimes sketching quick portraits of subject types who occupy these spaces. Thus some ads personify Capital in the idealized figures of a 
highly mobile business elite, while others offer tightly condensed apocryphal stories of success and failure. No less than the landscapes they occupy, representations of a contemporary business and technology elite thus reflect certain characteristics associated with the new information economy: flexible accumulation, de-territorialization, space-time compression, electronic markets and incessant technical innovation.

Corporate ads thus celebrate the surface of global capitalism, but the landscapes and portraits they imagine often express social and cultural contradictions even as they seek to suppress growing disparities in wealth. This kind of advertising discursively legitimates neo-liberal market capitalism by leaving out the consequences of capitalist institutions on nonelites, especially those who own nothing and those who have no recourse but to overpopulated labor markets. But while political-economic inequalities rarely register in these ads, there is no corresponding repression of the cultural contradictions that Richard Sennett (1999) traces out in the Corrosion of Character. What happens, Sennett asks, when individuals actually internalize the requirements of flexibility, risk, and job and geographic mobility? For one thing the ideals of close familial relations between parents and children suffer. Hence we may see the celebration of flexibility and mobility in ads, while also encountering "landscapes of fear" and "abandonment" (Gold and Revill 2003; Salerno 2003). Advertising frequently pivots on fear by offering to resolve the fear of loss (in this case, separation from loved ones) with an appropriate commodity, service, or symbolic corporate father. A 1999 Allianz ad exemplified this with a symbolically condensed scenic drama that evoked the anxiety of parent-child separation and the loss of that love, but trumped that anxiety with "the promise," a reference to the sanctity of personal character made possible by an omnipresent and caring corporate infrastructure distributed throughout a necessarily fast paced, mobile world.

The imagined landscape of stratification that takes shape across the body of advertising is driven by the contradictory needs of corporate advertisers to position their commodity interests and their quest to preserve their public standing as legitimate institutions. Hence while ads endeavor to glorify the distinctions of status, honor and privilege that come from inequality, they also seek to repress and deny gross inequalities because they threaten the legitimacy of the system.

How does the "capitalist realism" of corporate ads portray the social relations of production circa the millennium? Is this "capitalist realism" or something closer to the postmodern simulacrum that Jean Baudrillard theorizes? It may be that elements of both are at work in the constitution of these representations. As we explore the following questions we want to keep an open mind about whether the representations derive from the referents or if the representations are the original - are we looking at a substitution of signs of the real for the real? With that in mind, what role do markets and commodities play in people's lives as represented on the small screen? What does the capitalist elite look like and how are they related to those who produce or those who are denied access to the social surplus? How does technology redefine the categories of producers in these representations? What groups rise in importance? Who disappears? Who are the managers of capital, the information workers, the entrepreneurs, the individual investors, the manual laborers, the farmers, the poor? How are their images gendered and racialized? What happens to the frames of social class? How are spatial representations of the relations of production linked to axes of control and agency?

\section{Social Relations in a Universal Market}

In a capitalist society the commodity relation becomes the standard form of relationship. Money may seem to be the driving force of capitalism, but its importance derives from the deeper workings of the capitalist system. Beneath the surface of the cash nexus lies the structuring logic of commodity relations. Karl Marx's analysis began with labor as a commodity (wage labor), in which the real laboring activity of individuals was transformed into abstract labor to make it possible to freely substitute one person's labor time for another's. Labor measured in standardized units could be compared across time and place, making possible a universal currency that could turn all non-equivalents into equivalencies.

Once this process of wage labor took control, the commodity relationship extended into consumption relations since one now had to purchase one's needs through the wage. Marx saw capitalist development pushing commodity relations into more and more areas of life. This historical process has taken nearly two centuries to play itself out until few relationships in our lives have not been transformed into commodities in the universal market.

Advertising stands in a necessarily ambivalent relationship to commodification. Advertising is fundamentally 
involved in processes of universal commodification -- marketers and advertisers assist in extending the commodity relationship to ever more arenas of life. Yet, in order to secure viewers' interpretive cooperation, advertisers may also feel compelled to distance themselves from the results of commodification and their role in the relentless drive to incorporate all that is meaningful into the universal marketplace. Advertising blankets the cash nexus with narratives and signifiers that situate the meaning of commodities within noncommodified relations. Since commodity exchange is the presupposition of every ad, we do not need to be told that each product has a price - we simply understand that the good or service being promoted has a price to be paid for with money, or its functional substitute, the credit card.

While advertisers have an obvious self-interest in repressing the conflicts that surround class relations, they cannot ignore the cultural uneasiness prompted by the extension of the commodity form and "callous cash payment" into more and more areas of social life. Marx described the social and cultural consequences of turning everything into capitalist markets.

"It has pitilessly torn asunder the motley feudal ties that bound man to his "natural superiors," and has left remaining no other nexus between man and man than naked self-interest, than callous 'cash payment.' It has drowned the most heavenly ecstasies of religious fervour, of chivalrous enthusiasm, of philistine sentimentalism, in the icy water of egotistical calculation. It has resolved personal worth into exchange value" (Marx and Engels 1848/1978:475).

Historically, the relentless extension of commodity relations has undermined traditional values, promoted extreme individuation, and reduced decision making to cold commodity calculation. When market forces dictate values, there tends to be less social stability as "all that is solid melts into air, all that is holy is profaned..." For this reason, ads seek to arrest the process of change when it comes to the supposedly deep values held by AngloAmericans regarding that which is "holy" - family and community. Though the combination of labor markets and universal consumption has "reduced the family relation to a mere money relation" advertisers seek to reassert the "sentimental veil." Ads ranging from McDonald's to MasterCard to AT\&T to Arthur Andersen to Nortel swath the imagery of commodity consumption in emotionally meaningful scenes of parent-child bonding. Advertisers consistently seek to disguise the impersonality of market forces with a fabricated tapestry composed of signifiers of warmth, community, social comfort, and caring.

In corporate advertising the handshake is used to stand in for exchange relations. When a farmer greets a Dow representative with a handshake, perhaps he is thanking him for the chemicals that made possible the bountiful corn crop in the background. The handshake reaffirms the corporation's presence in the farmer's life. But where is the moment of exchange? This side of the exchange relationship is invisible. Though the consequences of using corporate commodities or services may be visible, the actual flow of commodities is less visible (though implied), and we do not see at all the flow of capital that returns nor do we see the labor that produces that capital. Even as capital reduces all commodities and relations to exchange value, the handshake symbolically reverses all this, transforming the formal contractual relationship back into the appearance of a personalized Gemeinschaft relationship. It adds a human touch to the cold hard logic of capital. It connotes neighborliness and friendship and brands the corporation with these meanings. The handshake offers a recognizable signifier of a mythical time when the forces of community and friendship shaped the character of men's dealings with one another. The handshake signifies a unification of the dual Myths of Patriarchal Individualism and Jeffersonian Gemeinschaft. Here the handshake imagery draws on hazy notions of a precapitalist space where a multiplicity of bonds determined the character of people's dealings with one another. Even though these corporate handshakes are abstracted gestures that occur in placeless spaces the handshake remains unshakably a marker of a just and fair exchange among equals. As a signifier it suggests consensus and an absence of coercion. Social relations appear guided by norms of mutuality rather than the calculus of contracts.

While advertising discourse spectacularizes the power of the commodity to enhance social relations, the real nitty-gritty of producing value is either omitted, abstracted, or aestheticized. Advertising spins a narrative web of commodity fetishism and technological fetishism. Viewers become so acclimated to seeing objects of value apparently materialize out of thin air, that they do not express alarm until their paychecks disappear. Neither does advertising dwell on the amount of labor necessary to acquire the cash equivalent to participate in the exchange. As advertising seeps into every nook and cranny of our social lives, it becomes increasingly difficult to take a critical position toward the process of commodification. While a critical assessment of commodification lies well beyond the discourse of advertising, advertising is curiously sensitive to popular criticism of 'over-commercialization' or 'crass commercialism.' Indeed, when relations are viewed as merely conduits to making money, then the words 'vulgar' and 'dirty' come to mind. Hence at the same time that ads seek to turn what is valuable to us into new sources 
of commodity value, more than a few campaigns seek to distance themselves from that process by conjuring up a nostalgic desire for living in a non-commodified world.

Distancing a brand from the logic of fetishism may involve claims to authenticity based on the assumption that commodities have no soul, but rather masquerade as authentic in search of an easy buck. The semiotic divide between authenticity and the inauthentic is by now familiar (Goldman \& Papson 1996). Another strategy exposes the metacommunication that underlies the advertising project itself to discredit competitors. Metacommunication is usually tacit, a set of assumptions that premise the manifest communication taking place; that is, the dimension of price does not need to be stated, it is understood. By leaving aside the matter of price, most ads sidestep the messy and conflicted terrain of privileging exchange value over use. Similarly, when consumer-goods ads routinely seek to invest desirable human traits in the products themselves, they do not normally draw attention to doing this in a self-conscious manner. But as audiences become more savvy about advertising gambits, some advertisers acknowledge the tacit assumptions in order to regain the trust of consumers and gain a competitive advantage through a differentiated brand position. Sprite's "Image is Nothing" campaign mocks the premise of commodity fetishism to distance its own brand image as beyond such infantile practices. By disclosing the logic of puffery Sprite lays claim to being a brand that sides with the consumer.

By contrast contemporary corporate advertising is less likely to engage in this kind of self-reflection because corporate ads more often promote the institutions that organize the exchange, circulation, distribution and production of the commodities themselves. In corporate advertising, the tone of voice is more sincere and less cynical about the commodification of place, sentiment, and social relations. Capital positions commodification as an inevitable process driven by technological advances, neatly reversing the relationship between commodification and technology. In corporate advertising, commodification coincides with an antiseptic, tidy, civil society where intelligent corporate stewardship of technology and capital turns alienation on its head - distilling out the cold, impersonal calculus of market logic. The process of globalization is contingent upon the free movement of capital and its products and services into all social relations in all cultural settings.

\section{Three Cheers for the Warm Fuzzy Dollar}

And yet, specifically amongst companies involved in the flow of money or its equivalents, there has emerged, circa the millennium, an inclination to soften their quest to turn the entire world into a stage for callous cash exchanges. Banks and credit card franchises feel compelled to remind viewers that though their business revolves around pushing the commodity framework everywhere (e.g., VISA) they remain committed to a moral hierarchy that recognizes our nearest and dearest relations can never be reduced to commodity form. Citibank ("Live Richly"), Chase ("The right relationship is everything.") and Bank of America, three of the largest banks in the western world, all stress the importance of that which cannot be commodified - love and caring amongst family members or the experience of true friendship. This has long been the strategy of MasterCard's campaign structured to call attention to the prices of commodities that we want and need for specific occasions, as a prelude to stressing that the relationships and experiences we most value are "priceless."

MasterCard's long-running "Some things money can't buy" campaign blends two themes: disposable income and quality time. Simply, if you have money you can provide for your family: insurance, medical care, a baseball game. Constructed out of warm fuzzy music and caring parental glances, ads in this genre exaggerate the moment of care while refusing to acknowledge the moment of exchange. MasterCard defined itself as an exception: its ads foreground the costs of things. MasterCard ads follow family members traveling the world sharing meaningful moments -- a couple celebrates their anniversary in India, another travels to China to see the Great Wall, a daughter takes her mother back to her home town in Ireland, best buddies fulfill a pledge to one another to attend a game in every major league baseball venue, and parents and children share quality time. In one ad, we even see the father hand over the gold MasterCard to pay for food and souvenirs at a baseball game. But here the ad's sleight of hand transforms the moment of exchange into a moment of care. The narration turns the moment of exchange into the necessary means of achieving the greater goal - the priceless as an end in itself.

Two tickets: $\$ 28$

2 hot dogs, 2 popcorns, and 2 sodas: $\$ 18$

one autographed baseball: $\$ 45$

Real conversation with 11 year old son: priceless.

There are some things money can't buy.

For everything else there's MasterCard. 
Accepted all over -- even major league ball parks

The commodities, and the credit card that permits their universal acquisition, serve a higher purpose - achieving a meaningful bond between a father and son. "There are some things money can't buy." The experience of bonding with one's child could become commodified, but then it would be an alienated relationship. And yet all those purchases made to take the kid to a major league baseball game - those purchases that set up the conversation - aren't those sort of an attempt at buying your kid's love?

Campaigns like this naturalize the universality of commodity relations while reassuring that the market is not antagonistic to those affective personal relationships that ought never be reduced to a price. But such ads also divert attention from mechanisms of generating and allocating surplus. Never mind the $24 \%$ default interest rate if there is ever a glitch in repaying the debt on the balance sheet. Usurious interest payments on credit card debt or loans are vaporized amid the social bonding. Rhetorically, Bank of America ads pushed the envelope further, touting the nobility of altruistically contributing to the greater good rather than simply seeking the greatest self-interest, while also criticizing those who wear the blinders of the commodity form and thus lack vision: "People who know the price of everything [but] the value of nothing."

\section{The Re-visioning of Class Formations}

While considerable evidence points to a widening income gap and burgeoning disparities in the distribution of wealth spurred on by the globalized "free" market economy, television representations of inequality and difference are moving in the opposite direction. Social critics point to a new binary in which the concentration of wealth disproportionately ascends to the smallest fraction of the population. Films like The City of God provide a glimpse of the suffering and death associated with the poverty of Brazilian slums. World news can scarcely avoid occasional photographic reminders of the dire forms that extreme poverty takes -- Palestinian refugee camps, drought-stricken Ethiopia, victims of civil wars in the Sudan, the congested cities of South Asia.

Yet, even as divisions of inequality deepen across the global landscape, the concept of class -- much less, class conflict -- is scarcely visible in the world of ads. Over the last few decades, industrial labor and the production of goods have steadily disappeared from ads. Today material production has been reduced to fleeting signifiers of selfmoving, apparently autonomous, technologies. Social class as a function of occupational location is occasionally reinvoked in ads, usually as a means of hailing potential consumers - the most obvious instance involves selling tough trucks to tough working class men. Glimpses of the working class are at best transitory in most corporate ads - a passing shot of a hardhat, or Chinese stevedores unloading a ship, or shots chosen to evoke the historical authenticity and durability (e.g., construction workers building the New York Life tower) of contemporary corporate entities.

When an occasional allusion to craftsmanship is made, the reference is to pre-industrial capital, or intriguingly, to post-industrial capital, where computer-driven machinery permits a smooth precision compatible with a craftsmenlike view of quality, sometimes without the presence of human beings being required at all. As with commodity advertising the site of material production is largely absent. When signifiers of production do appear, they take the form of high-speed automated robotics. When workers are present, they most likely gaze at control panels and other simulations of the act of production. If we see either factories or workshops, workers have been turned back into adjuncts to computer controlled tools - this is not the first time in the history of industrialization that workers have been depicted as machine tenders, but this time the role is glamourized by the presence of glinting, streamlined high tech tools -- or they have disappeared altogether. Though the work shown is probably still tediously repetitive manual labor, the references are so brief and the setting so glamourized, that the possibility of alienated activity seems remote. Value seems to be produced magically without labor.

A 2005 Bank of America commercial both references the new global proletariat while also burying their appearance beneath a discourse about perfecting customer service. The ad features an African-American corporate banker at Bank of America who is in charge of seeking perfection - zero tolerance for errors -- in check processing. As surprising as it might be to see an African American featured as a corporate banker, more surprising is a scene that lasts barely two seconds -- the scene that captures the new global working class, employed not as industrial workers but as check processors. Like their boss they are people of color, apparently Hispanic, Asian, and African. But there the similarity ends. We might guess that they are largely immigrants, and we can see they are female by a 
two to one ratio. The remainder of the ad visually swamps this scene with one shot after another of the equipment and software through which the high speed processing of checks occurs. This ad permits us to disentangle a set of self-contradictory representations: first, it is unique, no other ads acknowledge this stratum of office workers in the 2065 ads we've examined; second, this ad contains a kernel of truth, this is how computer-age proletarian work has evolved, no longer on the industrial floor, but doing repetitive data entry and paper processing tasks - more often than not, these tasks are outsourced to the Caribbean; and third, the disposability of these workers can be calculated in relation to the visual centrality and importance of automated machinery that now drives the circulation of money.

Class does not entirely disappear, but it ceases to exist as a function of production. Instead, class continues to be meaningful in the sphere of consumption and aesthetics. Ads for upscale hotels like Doubltree, Westin and Starwood aimed at business elites reaffirm Pierre Bourdieu's discussion of social class signified by an aesthetic disposition expressed through the pure gaze, which "implies a break with the ordinary attitude towards the world which, as such, is a social break" (1984:31). Elite status turns into a series of consumptive choices made by people who possess a self-reflexive appreciation of refined sensibilities.

Questions of class position are not transposed to the sphere of consumption alone, but also to the sphere of investment. This in itself is unsurprising. What is surprising is the new relationship between investing and social class as defined by ads. The ads redefine investing not as an elite domain but as a sphere accessible and available to everyone regardless of race, gender, creed, and even class. As implausible as it may seem, ads redefine investing as beyond class, as part of a post-class social landscape.

In the new capitalism, everyone is pictured as having access to the means of acquiring wealth via their investments. This is taken to its jovial limits in an Ameritrade ad set in an English language class for immigrants. This melting pot of persons from Africa, South Asia, Philippines, Eastern Europe and Latin America may not understand much English, but they quickly assimilate the economic culture as they show their teacher the joys of Ameritrade and the ability to trade stocks on your computer. This tribute to the proprietary excellence of Ameritrade is quickly expanded by ad's end when a Russian émigré exclaims, "And they said capitalism would never work" while the word "believe" settles across the screen. The stock market boom set in motion a frenzied competition to reach the great unwashed (as far as stock trading went) and reduced sales commissions quickly attracted many who had never traded stocks before and were eager to get rich quick along with everyone else. This vision of trading stocks abolishes all hard and fast stratification boundaries - here is the long-awaited utopian capitalism where the possibilities of achieving prosperity are available to all, where there appear to be no structural losers.

Of course, such a conception requires that we push aside questions about where profits come from. This view of a universal stock market requires either the open admission that some other group is getting the shaft elsewhere, or the pretense that investment only produces win-win situations. No one will acknowledge the former as a possibility, but the latter kind of rationale is advanced by Travelers in a series of 1998 ads that give voice to the narrative rationalizations of middle class investors about how their investments will benefit themselves along with distant others in the developing world.

One ad pictures a youngish woman seated amid her sedate middle class furnishings, musing to herself about how that dollar she invested will go to "South America to build a gas pipeline over the mountains, so people in Chile can have clean air and hot showers. And the pipeline is gonna help the economy, and that's gonna help my dollar so when it finally comes back to me it might be more like \$4. And I might be more like looking at the real estate section.” The investment process seems tranquil and serene, almost dreamlike in the way the scenes are edited, without a hint of coercion or unequal exchange. In fact, visually the process takes place without any exchanges whatsoever, although as her discussion moves to the economy and her return on investment, the landscape of Chile turns into an aesthetically pleasing, abstract waveform pattern. This sine form pattern with its imagery of recurring flows suggests a metaphor for consensual intercourse in the marketplace.

A recurring social type in the investing landscape is depicted as a fresh kind of savvy and independent investor with entrepreneurial spirit. Suretrade ads featured self-identified "mavericks" and "pioneers," a new breed defined by a shift in attitudes and paradigms - they are not looking to government to solve their problems nor to large corporations. They are confident that new computer technologies applied to trading stocks will create a democratized playing field that puts them in the driver's seat. Structured as a montage of soundbites arranged to form a serial soliloquy, three Suretrade ads construct the following ideological self-portraits.

$1^{\text {st }}$ young woman: "We're not relying on the government."

Young man: "We're not relying on the company." 


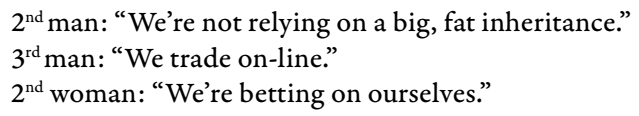

Young woman with a laptop on the couch: "We don't need a financial babysitter."

Young man: "We're declaring our independence."

$2^{\text {nd }}$ young male: "We're realistic, but hopeful."

$3^{\text {rd }}$ male: "We'll find our own way."

$2^{\text {nd }}$ woman: "We work harder for ourselves than anyone else will. We're pioneers."

Young man at his keyboard: "We're not caught up in the hype of technology, we're just using it."

Young woman: "Corporations are slower than we are."

$2^{\text {nd }}$ man: "We are a million individuals.

Woman with daughter and pet rabbit: "We're modern capitalist mavericks."

$3^{\text {rd }}$ man: "We're shattering the old broker universe."

These portraits resemble those of the skilled information workers to whom we will shortly turn. They tend to be young, confident, self-contained, and unconstrained. Their apparent social and economic well-being represents a function of their own choices, not the gifts of inheritance nor of entitlement. These portraits are all set in the individual's homes, spaces they apparently control, where they smugly declare themselves capable of self-motivation without the whip of authority to spur them on. They are not simply individuals; they represent a new social class of "maverick capitalists" who refuse to bow to convention or to the hierarchical system of doing things set in place by a Brahmin broker elite. As do-it-yourselfers they play out a populist imaginary for an era of networked technology, where those who make themselves savvy in the use of new technology lay claim to being more agile and swift than the behemoth corporations.

Related to the Suretrade representations, and mirroring what Richard Florida (2002) has called The Rise of the Creative Class, is an emergent form of "alreadyness" in ads for financial devices, investing, software, computers and telecommunications that hails the "creative" subject. This expressive subject feels restricted and unfree within the confines of bureaucratic organizations, aspires to own his or her own business, or to work from home, or seeks to invest with sufficient success that she can pursue her goals independent of the marketplace if necessary. American Express ads feature subjects who possess "vivid imaginations" in its campaign for the small business card - they are restaurateurs, chocolatiers, landscape designers, dress designers, veterinarians, architects, wine merchants, bakers, and sculptors. Microsoft's ads often seek to position its name as synonymous with a new stage of human development that aims at customizable freedom - no dream is impossible and no person or place is insignificant. The new Capital (e.g., Microsoft) exists to serve the self-expression of the sacrosanct free-standing human subject: "At Microsoft we stand in awe of you and your potential. It's what inspires us to create software that helps you reach it." Moreover, like American Express, Microsoft ads promise that their tools and instruments transform creativity into economically lucrative ways of life.

Microsoft's 1999 "Breadman" ad illustrates the new entrepreneurial imaginary situated in the landscapes of small town community. A traditionally working class position is thus transformed into an icon for the nouveau middle class creative who is simultaneously the anchor of a small town Gemeinschaft network. Microsoft's "Breadman" imagines himself as thus independent - a franchisee, networked with other franchisees -- able to pursue his own dreams, and much beloved by his fellow townspeople. "Who wouldn't want to be the bread man? Wouldn't you want to walk around and be the bread man? Everyone walks around and says 'hey, that's the bread man."'

\section{The Empty Binary of Class Relations}

As a corollary to re-visioning class formations, the over 2,065 TV ads we've studied rarely represent any relationship between classes or class actors. Fragmented glimpses of figures who are marked as possessing a class position are either narrated without the frame of class as a category, or keep such figures isolated. And as Hegel long ago reminded us, a master is not a master without a slave to recognize him as such. It is not surprising that images of the world poor are mostly absent from the landscapes of corporate advertising. When the poor do appear, it is to demonstrate that human dignity has not been forgotten and that corporations like Philip Morris, American Express or Occidental Petroleum care about people and empathize with profound human suffering. The poor, as we shall see, 
retain this semiotic functionality in how capitalism is represented in its own media.

While the poor are rarely depicted in television advertising, capitalist elites are not quite named as such either. This does not mean that corporate executives are invisible, but that questions regarding their social and economic rank and clout are kept blurry. It is frequently difficult to tell if a corporate executive is supposed to be a CEO, a vice president, or a manager. Few campaigns specify or differentiate functional responsibilities within the corporate hierarchy.[1] When real CEO's appear, as in NASDAQ ads, they are positioned as dynamic dreamers who recount with excitement, passion, and authority their pioneering places at the center of the new capitalist universe for the 21 st century. Along with professing infinite faith in the entrepreneurial path that has enabled them to gain wealth and success, translating visions into reality, they reiterate a litany of motivational maxims (e.g., "Success is not an entitlement, it has to be earned") that are intended to articulate a future of global capitalism composed by companies that have just "scratched the surface of what's really possible."

The NASDAQ ads reveal more, however, than intended. Establishing the visionary character of corporate leaders who possess a "passion" for realizing their visions, the ads play to a mythology of the new economy -successful companies depend on leaders who are innovative, inspirational, and have a courageous "entrepreneurial spirit." In these representations, the CEO's are the companies; they have engineered productive facilities that are devoid of workers. The leading edge of contemporary capitalism seems to be constituted by companies defined by passionately engaged, forward-thinking leaders, automated technologies, and products. This campaign hails the champions of the new economy, where the lion's share of rewards go to celebrity players, the "visionaries," while everyone else gets downsized, and once out of sight are also out of mind.

The NASDAQ ads are particularly instructive in narrating the linkage between philosophy of corporate organization and motivation that drives the leaders of Dell, Starbucks, Microsoft, Cisco, Staples and Intel. Similarly, Carly Fiorini, the first female CEO of a Fortune 100 company, took the stage in HP ads to narrate the philosophy of a firm rededicating itself to its roots in the "radical simplicity" of entrepreneurial invention and innovation. When Michael Dell, founder and CEO of Dell Computer, appeared in behalf of his company, the only allusion to his power was signified by the way he surveys the world through the window atop his company's grand architectural monument. In no instance, do these powerful corporate leaders speak of gaining wealth or fame or power, but rather of contributing to a "greater good."

"I like to think of myself as an Innovator who started a company - Dell Computer - around an idea that everybody should be doing business directly with one another. One to one - with no barriers. To me that's the power of the Internet. We'd like to show you how to empower your business in ways you'd never imagine. I'm Michael Dell and it's our reason for being."

His self-presentation as an innovator seeking to harness the power of an idea that serves to empower others rather than enriching himself suggests a new kind of world-historical elite that seeks not to preserve its own power but revolutionize the social relations of production to make everyone an owner and everyone a winner.

Fictional CEO's sometimes appear in "sign war" ads shaped by a humorous tone. Such ads seek to devalue the credibility of competitors. Here, fictional CEO's tend to be the other company's CEO's - they may be pompous windbags (e.g., XO), ball-busting tyrants (UPS), or ignorant and incompetent executives (EDS). Though such representations are usually facetious in tone, they nonetheless present the other side of the capitalist corporation -mistrust, abuse of power, incompetence, poor leadership, greed, insincerity, and a lack of innovation.

Television images of corporate executives also include glancing shots of them directing fiefdoms, issuing directives, demonstrating resolve, applying new technologies, jetting around the world, and reaping luxurious rewards. But by ghettoizing the "functionaries of capital" to a world of corporate towers, jet planes, haute architecture, and exotic resort hotel settings, these television images reveal no sense that a global underclass might be expanding or that the middle class might be eroding as a result of how Capital is expanding.

Michael Dell's pose as he surveys the world from the oversized window of his executive suite reminds us of Roland Marchand's observation that from the 1920s through the 1950s a recurring visual trope in ads was the executive gaze from atop a corporate tower. While such surveying gazes remain a signifier of commanding presence, today we are also apt to see corporate executives on the move. Through streets lined with corporate towers, through buildings, up stairs, escalators and elevators, through airports, in jets and on helicopters, executives symbolize dynamic capital, purposively and peripatetically in pursuit of the highest returns on investment.

A customary signifier of dynamic capital is suggested by tightly edited scenes of feet moving across floors, up stairs, through corridors, and sometimes even around the globe. Intercut into financial narratives, these signifiers of 
dynamic movement combine with the conventions of photography to connote power, purpose, determination and direction. Executives are often shot from low angle, a cinematic device that gives the figure a dominating presence in the frame. At other times executives are placed on high, suggesting superiority, vision, knowledge, and success. Scenes of executives striding in formation, flanked by aides and subordinates connote a sense of decisiveness and determination on missions that abstractly move toward achieving goals like mergers, takeovers, and lucrative contracts. The wingtip shoe is so clearly marked as a signifier of power that a Morgan Stanley Dean Witter ad uses the device of the shoeshine stand to play up the idea that Capital no longer discriminates against women as it includes a woman's high heel in the "new old boy's club." [2]

The formula for success is knowledge, power, mobility, and determination. Situated in positions of power, the corporate elite imagistically embody these attributes -- they are active, informed, determined, focused, surrounded by technology. Even when the body is not moving, information continues to flow via cell phones and electronic information tools integrated into the scenes. Embodied in pinstripes, wingtips, and the other accoutrements of power, these scenes suggest that markets may be volatile but capital is composed and disciplined in its pursuit of opportunities. Nowhere is this scenario more graphically played out than in the 1999 ad campaign for Salomon Smith Barney that reveals a world moving at warp speed while the elite investment bankers calmly survey it as they spot the "opportunities" that will pay off.

These representations resemble what Thomas Friedman (1999) dubs the "Electronic Herd" in The Lexus and the Olive Tree. His metaphor embraces the volatility of markets in conjunction with the diffusion of capital across the electronic circuits of finance. According to Friedman, no corporation or nation-state can risk losing the favor of the Herd. In the global economy this can be catastrophic to market values. Those who comprise the Herd compete to maximize the rate of return on investments, which translates into manically scouring the planet for opportunities or cutting losses as quickly as possible when it is time to sell. The manic need to invest is matched by panic selling. Combined with the ability to transfer funds and monies electronically, a stock can be cut in half in hours, or a country's currency thrown into crisis with a rapidity hitherto unknown.

Friedman's metaphor of the electronic herd pictures an economic elite dashing about in a global free market economy fueled by technological innovation and the liquidity of capital forms (currency, stocks, commodities). The figures who compose this grouping are constructed as dynamic, mobile, and technologically sophisticated. They fluidly traverse the world of nonplaces and occupy office suites in corporate towers surrounded by personal communication technologies. And yet, even in these idealized abstractions, uncertainties and anxieties seep through. Narratives of success are sprinkled with hints of impending crisis, or stories of those who made the wrong choices - the wrong office equipment, the wrong software, the wrong package delivery service. The exhilaration associated with accelerated social, economic, and technological change mixes with an undercurrent of apprehension. Speed may mean winning, but it can also lead to crashing. There are more losers than winners in casino capitalism. The landscape of risk is omnipresent.

\section{True Grit - The Persistence of Bourgeois Maxims in the Age of Globalization}

In spite of dramatic changes evident with the transition to global capitalism - internet networks, the stress on speed, the demise of place in favor of the flow of spaces, the decline of old fashioned virtues such as aversion to debt in favor of the stress on the necessity of consumerism - the rhetoric of motivation remains unchanged. Corporate ads still sound like the fictional success stories so popular in the late nineteenth century - like the Horatio Alger stories with their emphasis on individual pluck and determination. The further corporations drift toward concentration and consolidation, the more they seem to fall back on the work ethic and its associated ideological maneuvers.

We have seen that new rules, new tools and new relationships mark off the depiction of a new business paradigm in corporate advertising. And yet, no matter what else changes in the landscapes of capital, the ideology of motivation and success continues to rely on the moral maxims of the work ethic. A 2004 Smith Barney campaign hails the work ethic as the basis of business success. Employing the serial monologue, multiple executives delineate the key terms of their work ethic, as if they speak in a unified discourse. A key difference between this enunciation and that performed by their bourgeois precursors is that it's no longer the sole domain of Anglo males - the old fashioned work ethic is now an equal opportunity ethic that draws race, gender and ethnicity under the same umbrella. The Smith Barney ad opens by superimposing a white male over the financial landscape to suggest power, knowledge and determination. This is followed by quick cutting close-ups of Smith-Barney people on the move, each of whom address directly with 
confidence and conviction about what is required for success - theirs is the language of motivational clichés. There are no slackers here. They have been weaned out. Neither is there any secret of success, but rather a series of oldschool motivational homilies about the values and practices of preparation, elbow grease, stubborn determination, will, dedication.

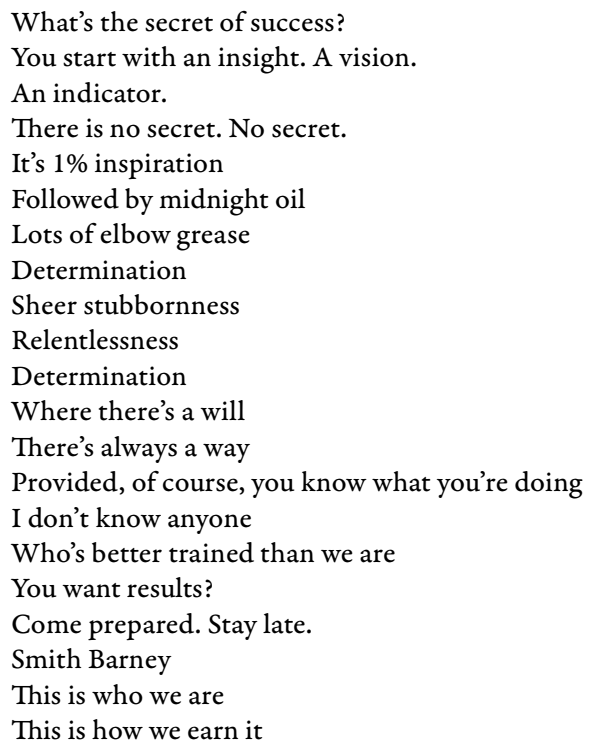

Charles Siebel "makes application software that let's you give your customers personalized service." However the imagery it invokes is not of the modern computer landscape, but of a solitary cowboy mending fences on the snowy high plains. "Once when you took on a job you did the job start to finish." In an age of high tech software applications and e-business tools, Charles Siebel positions itself as dedicated to doing the job right. Just like the ruggedly stalwart, inner-directed cowboy who takes pride in a job well done without someone monitoring him because he feels a deeply ingrained moral obligation to do so, so too this corporation maintains the highest moral standards vis-à-vis their customers not because someone is mandating it, "No one had to. It's our job."

Zygmunt Bauman (1999) draws our attention to the contrasts between the historical stages of heavy and liquid capitalism. Heavy capitalism designates that stage of industrialization in which capital depended on a massive, fixed infrastructure with industries like iron and steel in the lead. Material solidity was the hallmark of this era and its values seemed correspondingly stable, chained in time and place. The movement toward liquid modernity is characterized by a shift to electronic flows of information and a movement toward fluidity. Contemporary corporate ideologues praise all that is mobile, flexible, and agile, yet these very attributes of light capitalism and liquid modernity yield cultural values of inconstancy and weightlessness.

In ads like this for New York Life the solution is to reclaim the heavy metaphors of the past to describe the contemporary corporation. This notion that corporations need to define themselves by sincere pledges of allegiance to enduring values permeates the advertising of New York Life. Aware that the fixation on celebrity and the cult of personality yields ephemerality and a loss of depth, New York Life stresses their corporate fidelity to the abiding values of integrity and humanity. "What stands the test of time?" asks their narrator. The answer lies in values that insure security in a rapidly changing world. "Integrity is our foundation," declares another ad that anchors the firm in history-mediated imagery of muscular labor constructing monumental buildings of stone and steel.

When the headlines are about corporate fraud, accounting irregularities, embezzlement, price fixing, cost-cutting at the expense of quality, and warranties that are nothing but fine print, it is to be expected that a nostalgic mythos of a shimmering past will be invoked to shore up a value system driven by the necessities of an incessantly shifting marketplace. But this true grit floats like a signifier, summoned from an image bank of our past and fashioned into a pastiche that calls itself by the names of past virtues (hard work, integrity, pride of work and of one's word), as if conjuring up their images will insulate us from a fickle culture of images.

\section{The Modern Nomad - Seeking Equanimity in a World of Non-Places}

Zygmunt Bauman conceptualizes contemporary elites and nonelites by their relationships to space and time, 
with mobility as the primary indicator of class.

Tourists move because they find the world within their (global) reach irresistibly attractive - the vagabonds move because they find the world within their (local) reach unbearably inhospitable. The tourists travel because they want to; the vagabonds because they have no other bearable choice. The vagabonds are, one may say, involuntary tourists; but the notion of 'involuntary tourist' is a contradiction in terms (1998: 92-3).

An estimated 25 million persons work in foreign countries for global corporations. Trade agreements such as NAFTA have eased restrictions on corporate and business executives, professionals, and highly skilled workers as they move from one country to another (Anderson and Cavanagh, 2000: 25). Capital's privileged classes tend to be globally mobile, unbound to place; they match the fluidity and liquidity of Capital and traverse national borders with ease. Equipped with the technologies of mobility -- laptops, cell phones, platinum credit cards, and wireless connections to the global information system -- the globe-spanning nomadic elite inhabit what Marc Augé describes as the 'non-places' of supermodernity, a nomadic institutional structure designed to facilitate their cosmopolitan wanderings - (e.g., elite hotel chains and VIP lounges).

Clearly the word 'non-place' designates two complementary but distinct realities: spaces formed in relation to certain ends (transport, transit, commerce, leisure), and the relations that individuals have with these spaces... For non-places mediate a whole mass of relations, with the self and with others, which are only indirectly connected with their purposes. As anthropological places create the organically social, so non-places create solitary contractuality (1992:94)

In a 1999 Allianz ad entitled "The Promise," as a father prepares to leave for a business trip, his daughter poignantly asks "promise to call me?" His odyssey takes him through contractual spaces: airport, hotel, rental car, and electronic communication circuits. He is a global actor, assured and confident as he travels through spaces drained of time and place. The son of capital, he is likewise liquid and flows across the landscape. Allianz insurance underwrites the circuits of capital connected by these non-places, the insurance to cover the uncertainties in the ungrounded spaces of supermodernity.

Mobility. Covered by Allianz.

Risk. Covered by Allianz.

Performance. Covered by Allianz.

Technology. Covered by Allianz.

Life. Covered by Allianz.

The Allianz ad fuses liquid global capital with concern and dependability, muting the logic of capital through a familial analogy. Father to daughter is equivalent to Allianz and it clients. Like a father who thinks about his daughter during his travels, Allianz is always thinking about its insurees, "a promise is a promise. Wherever you are and whatever you do, Allianz with its global partners is the power beside you." And just as a father fulfills his promise to his daughter, Allianz will fulfill its promise.

Separately father and daughter gaze upward in their solitude, holding one another in their memories. It's an empty existence without the other. Using slow motion, superimpositions, dissolves, soft focus, pastels, in combination with the reassuring lyric, "no matter where you go I will be with you," the ad purports to keep alive the organic relationship in a world of supermodernity that has been stripped of any mothering female presence save token signifiers of a hired female caretaker's hands. A recurring social tableaux depicts absence from family members and the psychological response of longing. The moment of identity is the father/daughter relation; their pleasure and affect are connected to each other's voice. Satisfying as this paleosymbolic drama might be, the prospect of singular identity is unlikely found in the emptiness of non-places.

What he is confronted with, finally, is an image of himself, but in truth it is a pretty strange image. The only face to be seen, the only voice to be heard, in the silent dialogue he holds with the landscape-text addressed to him along with others, are his own: the face and voice of a solitude made all the more baffling by the fact that it echoes millions of others. The passenger through non-places retrieves his identity only at customs, at the tollbooth, at the checkout counter. Meanwhile, he obeys the same code as others, receives the same messages, responds to the same entreaties. The space of non-place creates neither singular identity nor relations, only solitude, and similitude (Augé 1992:103).

While Allianz fashions an emptiness of home to match the emptiness of spaces passed through, AT\&T affectively matches the solitude of non-places to the warmth of place. Elton John's "Rocket man" provides the 
emotional musical background to express the loss of closeness for the modern nomad. He pines for his home, his wife, his child, the Earth, solid ground. His is the lonely disconnectedness and endless travel of supermodernity. Against the solitude expressed in the lyrics and images of air travel AT\&T edits together a tapestry of images expressing warmth: the wife sleeping in a mahogany bed next to a bouquet of flowers, the daughter leaving for school, the wife in the kitchen preparing food, the child's purple violet broach that the wife slips into his briefcase. These are given narrative direction by the sequencing of his and her longing gazes. Longing is transformed into communication, a commodity exchange. He sends her a fax that reads "Meet me on the porch 9:00." The porch romanticizes the relationship. Shot in soft focus, it represents a haven from a heartless world. The demands of work and the nomadic existence experienced by executives are counteracted by tender memories of family life. Again, signifiers of a daughter are turned nostalgic. The Allianz and AT\&T ads speak to the social separation implicit in doing business in the high tech world of global capital, while at the same time reinstating emotional contact through the telecommunications circuits of high tech capital.

Even the winners are made to confront the fragility of a world where the social is falling apart. The modern nomads who circumnavigate the globe to do business may long for the warmth of place, but we find them instead in places of warmth. They must make do with a signifier of affection: a photograph, a hair broach, a faxed note, a memento. Although power and mobility are celebrated, the social tableaux of adverts suggest that Capital creates a less than perfect world even for its winners. These representations also capture the social and psychological contradictions of a fast-paced economy: exhilaration and worry, change and uncertainty, possibility and risk, mobility and longing. The volatility and instability of a fluctuating market economy produce anxiety, and like commodity advertising anxiety can be a powerful psychological force linking corporate brands to anxiety-alleviating strategies -- investment for the future, protection of one's family, successfully competing against invisible enemies.

\section{| Infrastructures of Anxiety}

Today's elite as portrayed on TV is defined by its relationship to financial capital, technology, and information. Advertising heralds the prevailing business-channel wisdom that technological innovation, when appropriately applied, provides a productivity advantage. But the ads also preach consternation that technological change will result in precipitate obsolescence, or that inappropriate technological choices can competitively doom a company. The logic of Capital has long necessitated creative destruction, but the process has accelerated. David Harvey's (1989) focus on time/space compression must be fused with technological innovation and market reaction. While corporate ads paint images of triumph and accomplishment, there are anxious undercurrents of uncertainty associated with the rapid turnover and instability of corporate structures, unending competitive pressures, market volatility, the difficulty of governing new technologies, as well as the unforeseen consequences of corporate decision-making. Nervous apprehension hangs in the air even for the most successful. As Hobbes noted long ago, the marketplace that is a "war of all against all" induces perpetual fear as well as perpetual motion. While corporate ads celebrate the exhilarating force of capital, a portion of advertising seizes on the undercurrents of nervous agitation amongst fearful executives who can never have enough information to make the right decisions. In this sense, firms like IBM, Microsoft and Oracle market their services in a therapeutic voice - offering cool confident consultants (technological, organizational, investment, marketing) or software that never gets rattled to restore a sense of serenity. In a business world that demands an incessant capacity for flexibility and adjustment, Microsoft Enterprise software makes the perfect employee because it does not have those pesky human emotions that make it vulnerable -- "the software is not flustered by this sudden turn of events, because the software does not fear change."

In a business world being overhauled by information technology, choosing the right technology solution is cast as a primary factor standing between success and failure. "Whether it's hardware, software, or service, it's your worst nightmare: Buying technology from a company that goes 'poof."' Not surprisingly, one type of anxiety and 'failure' ad highlights executives who chose the wrong brand of technology.

In a 1998 Oracle ad, an executive sits alone at a bar, mulling over the fate of his company and his career. While the depressed exec slumps over the bar eating nuts, the bartender refills his drink. No more mountains to climb for this guy, just lonely alcoholism as he ponders what might have been. His stature diminished, the only other person present, a woman in a red dress at the bar ignores him as she does some paperwork. He placed his bet on "just-intime" software when he should have gone with "integrated flow manufacturing." 
Executive: Three years and a $\$ 100$ million dollars putting in software for just-in-time manufacturing

Bartender: Yeah, so?

Executive: The world's biggest most profitable manufacturer just moved to something called flow manufacturing.

Bartender: Switch to flow.

Executive: I can't. \$100 million and my software doesn't support it.

Bartender: So, uhhh, what software do the big guys use?

Narrator: Oracle. The world's second largest software company is the first with integrated flow manufacturing applications.

Executive: Big guys. I used to be a big guy.

Advertising associates technology with corporate brands - this simplifies the selection process. But of course, there is significant risk in committing oneself to a proprietary technology covered by a brand name. Hence, Oracle ultimately sells itself as the second-largest software company as if that fact alone will insulate end users from making a decision that isolates them like the executive at the bar. Of course, the ad conceals the flip side of this anxiety coefficient, that no competitive advantage can be gained if you use the same tool that everyone else is using.

Complicated technological products are not easily translated into thirty-second narratives. Instead jargon catchphrases, such as bandwidth, networking, B to B, and flow manufacturing provide an abstracted shorthand that camouflages lack of knowledge and allays some of the trepidation associated with incomplete comprehension. Some firms now recognize how alienating high-tech jargon can be, and produce ads that joke about jargon and the anxiety it can induce.

Ads aimed at corporate decision-makers often focus on technological and organizational decisions. Either the technology seamlessly integrates into an organizational structure or it transforms the organizational structure so it can adapt to a techno-economic environment. As a genre these ads cultivate an atmosphere of anxiety associated with accelerating technological change. Organizational flexibility is celebrated as necessary to survival in a market economy that rewards speculative success. Nothing is static: the organization, the economic environment, nor the career trajectories of the players.

IBM's advertising leverages technological uncertainty to promote their products and services. Their ads join humor with anxiety to signify that in an era of rapid technological change, survival and growth are contingent on having an integrated technological infrastructure. Given the hypervelocity at which software and infrastructure change make a 'knowledge generation' obsolete every few years, in the informational economy technological expertise is often located at lower levels of the corporate hierarchy. Just as the middle class is at the mercy of plumbers, mechanics, and other tradesmen, executives strain to make decisions about technologies they don't quite understand. IBM ads often play on insecurities about insufficient technological expertise located at top levels of management. Their ads reveal executive company leaders pressured to promise too much growth too quickly until their organization starts to snap. In each ad this is followed by the tagline: "And that's when it hits you. You are so ready for IBM." IBM's 2001 campaign consisted of vignettes highlighting lurking techno-anxieties that haunt corporate leaders as they grow to their level of incompetence.

Lurking at the edges of other ads is an ominous corporate authority. Making the wrong decision unleashes his/its wrath (feared absent authority is not given female representation). Even when the authority is unseen, it is experienced as male. Films like Office Space, Fight Club and American Beauty capture the relationship between hierarchy, the absence of autonomy, and fantasies of transcendence often expressed as revenge. This is vividly brought to life in a humorous ISS ad for internet security systems that visits an executive who has been "let go." As he shaves, he engages in an imaginary conversation with his ex-firm, and he enacts his revenge - "now let's go of some things of yours." Since he retains his password information he begins to delete things like "accounts receivable for the last two years! Payroll, let go!" All very therapeutic for him as he continues to rage about how he has been ajudged as possessing a "below average employment history" (a reference to General Electric's system of evaluating personnel). Terminated!

IBM ads frequently address in joke form the trepidations, apprehension and fears middle management professionals live with in constantly being pressed to meet unreasonable deadlines and expectations. Another 2001 IBM ad plays on fears of downsizing following mergers and acquisitions and offers its own technology as the solution. Entitled "The Axe," this ads takes place in a darkened office. Silhouetted against a view of other corporate towers, in a darkened corner office, a corporate senior executive and a technical operations executive converse. The title, tone, and dialogue suggest that the CEO is about to fire his chief information officer, who expects it and has already meekly accepted his fate. This anticipation reflects the volatile instability of the economy and the corporate labor market. However, his real anxiety begins when he gets the news that he is not fired but instead has 
been assigned the merged job, and with it a task that goes beyond his technical abilities or experience - "the hairiest integration project ever. With servers, storage, databases, it needs the right guy." All is not lost however, since with IBM one can outsource the expertise and the solutions in the form of "business infrastructure" services.

A 2003 IBM ad presents a young woman executive restlessly pacing in a psychiatrist's office as she recounts her dream. "I'm floating in water." In a scene that is supposed to represent her dream, she is seated along with a small group of executives at a conference table that is at sea. Her voicing rising in alarm, "Can't you see we're adrift, we're lost," she tries without success to turn their attention to their predicament. The psychiatrist replies, "Ahhh, liquidity issues," to which she vehemently reacts, "No, water, we're at sea! We're rudderless, we need help." Characteristic of IBM ads, the response in her dream by her fellow employees to her distressed warnings is that "this is Bob's meeting, Beth." This small aside permits IBM to more effectively hail their audience of businesspeople who are likely to smile at this nod to the petty status games that often displace the real work that needs to be done. What does her dream mean? Her psychiatrist reiterates the obvious, "That you're lost, adrift and need help...Call IBM Business Consulting."

A 2004 Siebel ad fashions a slightly different tableau of managerial fear as a boss interrogates his sales staff about lead conversions rates. As each employee is called upon in turn, they already know they have underperformed and so hesitate with their answers while imagining their worst punishment fears. Jim imagines being lowered into a pot of molten metal. Nancy and Steve picture themselves drowning without a life raft in the open ocean. Another executive grimaces, visualizing himself about to be drawn and quartered by horses galloping in opposite directions. The screen turns to blue with "Say goodbye to that awkward, uninformed feeling" printed across it. Suddenly, the mood changes and each salesperson answers again, knowledgeable and confident about new sales leads and increased conversion rates.

As expectations concerning growth and productivity rise, so do the anxiety levels associated with meeting those expectations. Post-Fordist economic formations not only generate postmodern cultural formations but also sociopsychological tendencies contingent upon ones position in the economy. The Seibel and IBM ads seize on graphic visual metaphors, such as being adrift at sea, to capture worries associated with the uncertainty of performing in the informational economy where change is so pervasive that virtues of personal flexibility are simultaneously exercises in disorientation. These ads situate anxiety in terms of loss of control - the loss of faith in one's ability to stay current. Where mergers, corporate downsizing and re-engineering are the coin of the day, and where career paths erode and destabilize, there is an ever-present sense of vulnerability. Despite the therapeutic image of the psychiatric couch, the IBM suggests that the only therapeutic fix is a short-term commodity fix, and strangely, given a therapeutic culture that counsels fixing the self from within, the only way to solve the problems presented here comes with pleasing an external authority whose standards may or may not be legible (Sennett 1998).

\section{| Information Technology Workers}

Rooted in the microchip, computer software, and telecommunications industries, the information technology revolution has spidered out into enterprises across the economic landscape. Information networks and information flows have grown exponentially over the last two decades as more and more corporate institutions have adopted electronic networks. Adoption of electronic networks began with financial institutions and by 1990 "network applications occasioned a spectacular increase in capital expenditures that showed no signs of letting up."[3] Information technology workers are defined by the Information Technology Association of America as skilled workers who perform any function related to information technology, defined as the "study, design, development, implementation, support or management of computer-based information systems, particularly software applications and computer hardware." [4]

The telecommunications sector became a key driver of Internet expansion beginning in the early 1990 s. Telecoms invested heavily in the installation of routers and switches with the aim of providing integrated communication systems. Already deregulated in the 1980s, the telecommunications sector continued to be restructured by a focus on systems integration where corporations outsourced the management of their business computer networks to firms such as MCI and then WorldCom.

Digital capitalism also is free to physically transcend territorial boundaries and, more important, to take economic advantage of the sudden absence of geopolitical constraints on its development. Not coincidentally, the corporate political economy is also diffusing more generally across the social field (Schiller, 1999:205). 
Given their stake in being recognized as a leading systems integrator, it is not surprising that by decade's end WorldCom would define itself around the face of its information technology employees. WorldCom's generation D campaign positioned infotech workers as "in the know" employees who solve network problems with confidence.

One ad shown in 2000, follows a young WorldCom employee as he casually rides a scooter along the ramps and halls of a corporate campus, past fellow female and male employees, casually gathered in conversation or work, to his office space. One young woman sits perched atop a bookshelf with a laptop while three others informally lounge at a table drinking coffee (or herbal tea), all connected to their work via wireless laptops and handheld PDA's. There are no suits - no office dress code - in this office, because these are grown-up Gap kids.

They are not simply comfortable, but effortlessly at ease with themselves, with each other and their ultramodern, communal office spaces. Since they are not hung up on appearances, individuation takes the form of the unconventional. These unconventional moments define the landscape of the new corporate workspace because there is a total absence of visible authority in these spaces. Scooter-man is iconically essential to defining this workspace. The scooter represents his mode of expression as he flows through the workspace. So too in the Akamai campaign (2000) the scooter is semiotically displayed front and center as indexically marking the new breed of worker in the network structured workspace. In fact, the Akamai ad poses one of their new breed information workers next to his desk that features both his fancy computer and a no less fancy high-tech titanium bicycle (cousin to the scooter). Each is an emblem of his identity, and his identity is emblematic of the company's personality. The scooter signifies an unalienated attitude to work, the intentional choice of a free thinking, value-producing individual who chooses to work for the kind of company that respects creativity by providing the casual informality of fluid, unregimented workspaces. Even the artwork on the wall, a series of three successive shots of scooter man entering and leaving the frame, signifies the playfulness, informality, and creative thinking that permeate these work spaces. The replication of the image into its own repetition offers a marker of what a postmodern business aesthetic looks like. Is this the new exemplar of the "work of art in the age of mechanical reproduction?" While the scooter signifies the antithesis of the cubicle - with the cube farm representing the bondage and restriction of work, and the scooter standing for the freedom of digital work - no less important in this semiotic narrative is the representational form that calls attention to the reproduction of the image.

We wonder why both Akamai and WorldCom, each seeking to hail the creative information technology worker, would feature such elaborately contrived visual constructs to show off the reproduction of an image within an image? Each campaign takes pleasure and pride in the repetitive character of visual reproductions. They are displayed as art, and as self-referential humor. In the WorldCom ad the pictures on the wall seem almost constituted in real time - a suggestion that wall art can in fact be continuously produced, or reproduced, electronically. The Akamai ad uses a similar, carefully manufactured semiotic puzzle that is visually sequenced to the words "the internet is faster because of us." What is the semiotic calculus here? Five screens mounted on tripods stand in a grassy meadow. A yellow train speeds past from left to right across the background, with the entire scene reproduced synchronically on each of the five scenes in real time. While it is easy enough to surmise that the purpose of this is to demonstrate a faster internet, the manner in which it is done prompts some self-reflexivity about seeing screens within screens.

Like Pepsi, WorldCom advertising extends the social category of generation beyond age as merely an ascriptive category. The Pepsi Generation defined as valuing fun, excitement and caffeinated leisure have been included into this nascent corporate class defined by its attitude to technology. This imagined generation is hailed as WorldCom's totem group. Blending tech skills, corporate vision, youthful exuberance and Gap style, Generation D thrives on techno-social change. Work is play - it's a "joyride."

They're young. And some just think that way. The people in companies that were born digital, Or reborn. As comfortable with data as the last generation was with the telephone, as long as they have the right set of tools, and the right company behind them

While we conventionally think of a biography as a book length manuscript that covers a person's life from birth to death, here biography is hypersignified by a glance. We are positioned to imagine the rest. To be born digital is to be at ease with oneself and one's environment, to exhibit a certain habitus, ways of seeing and doing that are so deeply internalized they are experienced as natural, like being born a gentleman. However, the habitus of generation D trumps race, gender, and social class, even though signifiers of gender, race and class are overabundant, and their representations borrow on the bourgeois aesthetic of off-center portraiture to connote intelligence. A shared generational culture appears to shove aside social class as a classificatory device. Class connotes structure and 
hindrance; generational culture suggests choices, movement and progress.

The serial montage is a cinematic structure commonly used by firms in the information technology sector - and seems particularly favored by firms that compete in the networking sector (e.g., Cisco, Akamai, WorldCom). The serial montage links snippets of statements made by multiracial (skin color), multicultural (signified by clothing styles), multiethnic, multi-accentual (accented English), and multiregional (both rural and urban backgrounds) speakers. Each subject can be conceived as a serial node in the communication network. Participants recite phrases in a repetitive formula that establishes a shared commitment to the corporate worldviews that endow them with meaning, purpose and opportunities. Supporting the metanarrative of the communications industry that free, open and fast communication eliminates all distinctions associated with race, gender, ethnicity, and social positioning, the serial montage constructs a landscape with nary a hint of hierarchy or power relations.

In The Internet Galaxy, Castells (2001) suggests that technical performance trumps race in the ideological world of Silicon Valley and dot.coms. Seriality may well reflect the organizational ideology of the communications industry while failing to account for nascent structural formations and practices in a virulently competitive corporate sector.

WorldCom's 2001 ads used the series to construct an emergent global social strata connected not by place but by totemism. Successful commodity advertising interpellates its target audience as if it is already part of the group constructed by the ad (Williamson 1978). The brand then assumes totemic status representing and embodying the ideal qualities of the imagined group. Successful brand construction correlates totemic identification to a $\log$. Thus, the Pepsi generation constructed an imaginary group that was fun-loving, youthful, and leisure-oriented, a group whose social coordinates are dictated less by social practice than by the aggregation of market research. In Baudrillard's terms, this kind of totemism is rooted in the death of the social. The totem is thus a specter in a dual sense, a ghostly reminder of what has been lost and an imaginative phantom of desires not yet realized. Like commodity advertising, corporate branding also attempts to give its logo totemic status by associating the imagined group with its brand. It simultaneously constitutes and is constituted by these branded characteristics. WorldCom positioned itself as a corporation that supports technological problem solvers unconstrained by hierarchy or structure. WorldCom's generation d campaign defined its employees as cool and confident, 'in the know' because they had committed themselves to an innovative corporation. Most importantly, it opened space for potential customers to participate in the characteristics correlated with generation d. WorldCom sold freedom from techno anxiety through feel good associations (unlike IBM which uses techno-terror to push up the anxiety quotient until the business person can only cry for help). Melodic, upbeat corporate techno background music further heightened the sense of confidence that radiates from the portraits. Gen D's know where the world is going and backed by WorldCom they are the one's taking it there.

The frames in this series are formulaically equivalent as posed portraits -- each subject directly addresses the camera in a tone infused with technological confidence. The world moves quickly across the background, but the portraiture that composes the foreground stays securely fixed. Hierarchy and authority seem non-existent, rather beside the point. Composed by their differences of dress, gender, ethnicity and location, this emergent subculture nonetheless speaks a common language: English with an accent, mixed with a few technical acronyms. Stop action photography creates the impression of a futuristic world juiced on speed. It also uses place and culture (signified by accent, appearance and background signifiers) to signify difference and diversity even while the ad proclaims the emancipation from the confinements of place and culture.

Euro Male voice: Generation d isn't about the country...

Female: It isn't about culture...

English female: It's about attitude...

Female: [first in German and then in English] I'm from Germany...

Male: "Je vie la France...

Female: I come from Indonesia...

Asian female: I'm from Oklahoma...

Male: Oklahoma?

Female: But we speak the same language...

Male voice: Digital...

Another male voice: ....and we make it easy to understand.

The effort at disentangling the constraints imposed by old expectations about the unity of place and culture takes several signifying forms. When a woman of Asian descent, wearing signifiers of an Asian culture, drawls "I'm from Oklahoma" the disjuncture between cultural signifiers is sufficiently incongruous that the following speaker questions 
it. Wow, here truly is a liberated global society that permits people to move freely from one space to another, finding identity in a new group shaped by an attitude, a confident disposition toward digital technology. Another frame almost subliminally slips past as the name "WorldCom" and the address www.vote_democraticsociety.com appear on a wall as graffiti. No such website existed. The irony that the address of democratic society could be put into .com domain should not be allowed to go unnoticed, and let's not forget that WorldCom's financial collapse was rooted in old-fashioned fraud. Though these ads highlight flows -- of ideas, of information, of services, of commodities - they repress the reverse flow and accumulation of capital and the undemocratic ways that accumulation pools.

In the giddy euphoria that surrounded the explosive growth of the internet economy, the information technology worker seemed to have limitless opportunities. Companies aggressively competed for 'star' programmers, and many assumed that salaries throughout high tech would follow suit. However, with the shake out of the dotcom sector, the collapse of the tech market, and the increasing rationalization and integration of networks, this class may be turning into a new working class composed of cube farm info workers who experience mind-numbing computer work under the constant oversight of bosses, bureaucratic deadlines, and the always looming reengineering of jobs. As the entrepreneurs of the tech boom - Gates, Dell, Jobs, and Bezos - transformed their firms into ultra-competitive high-tech giants their rank and file have been inexorably turned into lesser-paid tech specialists. And it is by now a commonplace that software programming and call center jobs have migrated from the United States and Europe to India. The global search for cheap labor and subsequent downsizing extends well beyond manual labor as the search for cost savings moves up the infotech work chain.

\section{The Two Faces of Rhizomatic Labor}

However the WorldCom ads represent but one face of this technologically savvy stratum. A series of Peoplesoft ads in 1999 also stressed the incipient centrality of knowledge workers in the new economy. However, rather than celebrating an airbrushed portrait of Generation D, the Peoplesoft pitch is weighted in the darkened tones of worry and apprehension about the ceaseless waves of change that threaten to engulf those who remain static. The Peoplesoft representations stress the realpolitik of the new global capitalism by foregoing the fashionably multicoloured plumage of the new tech workers. Instead the Peoplesoft ads offer black and white lessons about the perils of failing to be ever vigilant. In the new corporate survival of the fittest, "Success today is network knowledge, intellectual capital. Inspire your people with the tools to collaborate. Nurture this and survive. Curtail it and become extinct." These are the new relations of production in the post-downsizing era, where flexibility demands an openness to an ever-evolving panoply of shifting partnerships and alliances based on innovation and collaboration.

Another Peoplesoft ad darkly counsels about the necessity of adjusting to the new social relations of production in an e-business economy.

"This is your future - The next generation.

They won't settle for life in cubicles.

They will demand access to information to innovate, collaborate.

Their branches will rupture your walls.

Their only boss will be the best idea and it can come from anywhere.

[pause for dramatic effect] Will they want to work for you or the competition?"

"Their branches will rupture your walls." Networking collaborators cannot co-exist with old-school corporate organizations and boundaries. It is almost as if this line was extracted from Deleuze and Guattari (1987) when they discuss the rhizome as the antithesis of "the tree" model of social organization "rooted" in hierarchical structures and linear thinking. Yet the Peoplesoft ad insists that the necessity of rhizomatic labor relations is a function of the stern determinism enforced by a capitalist economic competition that has already "cut down to the bone." Here we see the other side of capitalist social relations - not as opportunities for personal growth as such, but as the conditions made necessary by the shifting contradictions of Capital. Hence it is not surprising that this new class of worker is given no face at all, no personification, in the Peoplesoft campaign - they are what they are, a necessary human capital component in the value production chain.

Akamai is another company that operates a globally distributed network of servers to distribute Web content. Akamai ads closely resemble the WorldCom representations in the signifiers that have been selected (e.g., the scooter) as expressions of unconventional personality and the overall landscape of signification - a rhizomatic landscape fashioned to permit the expressivity of those who perform the mental labor that will spark the new information economy. Here we see flashing glimpses of high tech workspaces inhabited by multicultural portraits of the digital 
generation - like their counterparts at WorldCom they appear supremely at ease with themselves, and by inference, with their work. Spaces are open and unbounded and authority structures are invisible, where knowledge workers are free to express themselves via uniquely constructed pastiches of ethnicity combined with punk disregard for all past traditions of self-presentation. In these landscapes suited to the expression of personality, work is apparently place diffused. And yet, if we look carefully we notice that like the portraits of Generation D, the faces and bodies that fashion value in an idea economy are more or less motionless, rooted in abstracted places. All sense of flow comes from the camera's movements and the video editor's contributions, such that the vividly colored backgrounds seem to be in motion. The environment is open and without walls or limits, contriving a Internet simulated world without hierarchy or the restrictions of power.

It might be anticipated that scientists and engineers would be represented in ways similar to the rhizomatic stratum of communications and computing specialists, but aside from their relative individuation and apparent autonomy vis-à-vis any top-down authority, corporate scientists are bound by their uniforms and their dedication to the values of discovery rather than concerns about self-expressive posturing. Beginning with the GE ads of the 1950s and 1960s, the corporate laboratory has come to occupy the center of the scientific world. Corporate ads picture scientific research and engineering as essential to progress and development in almost every sphere of life. "Our three hundred thousand employees create and design the technologies that promise a future without limits" (GE 2002). In this context, corporate ads are particular insistent about keeping exchange values hidden behind the generalized halo of public values. Whereas, consumer-goods ads invoke science as a kind of magic that yields new product benefits, corporate legitimacy requires that some connection be established between the labor of scientific research, capital investment, and new public goods (e.g., cures for disease, greater abundance of crops, more efficient extraction of energy resources). Scientific research tends to be situated in open architecture spaces. Research scientists are indicated not only by their stereotypic lab coats and their proximity to microscopes, test tubes, or other laboratory instruments, they are also shown in acts of scientific inscription as they seek solutions to problems by writing on transparent plexiglass panels that connote the futurism of holograms. In this regard, it is not uncommon to see scientific researchers and engineers placed within virtual veils of representational notations or illuminated three-dimensional holographic images that simulate the underlying objects of inquiry or the inscription devices that translate nature's patterns into technologies of control. Women are as likely as men to appear as research scientists in the ads, even though they are less likely than men to be employed as engineers or physical scientists by corporations. Minorities are also better represented imagistically in the roles of medical researchers and engineers than in the actual labor force. Like everyone else in the corporate economy, their work apparently is self-motivated, requiring no external authority; and it is pursued either individually or in dyads. What disappears from these scenes are the ways in which the processes of industrialization, proletarianization and commodification have restructured the relations of science.

\section{Towards the Wireless Office}

One immediate implication of laptop computers, the internet and wireless communication technologies for those who work in offices has been the possibility of new spatial arrangements for doing work. In the capitalist workplace this presents clear tensions between the possibilities afforded by workforce flexibility and the fears of what might happen if employees are not continuously monitored for output. The same forces that untether employees also countenance keystroke counts. Whereas, the rhizomatic stratum might be encouraged to work at their own creative pace, less trust is afforded to those who are considered more readily replaceable.

An ad for Haworth Office Furniture titled "The ins and outs of 21 st century business" offers an instructive ideological expression of the changing parameters of corporate office work technologies in the new economy. The ad is structured as a series of semiotic binaries - what is "out" and what is "in." Interpreting the ad, we see that pretentious hierarchical forms based on access to closed offices are "out," supplanted by open, collaborative and hence necessarily more egalitarian team spaces. The inefficiency of paper waste delivered to bureaucratically separated desk spaces has been supplanted by cool, digital efficiencies of e-mail as a means of working in a distributed manner. Airplane travel linking geographic spaces is negated in favor of electronic video conferencing. "Walls are out. Wheels are in." The static formula of cubicles and divisions amongst employees is replaced by the flexibility of open architectures.

The hell of being cubicle bound is humorously exaggerated in a 3Com ad from the year 2000. Sharing a tightly enclosed space with an overweight co-worker who makes no effort to muffle annoying body noises - sniffling, nose 
blowing, snorting, clearing of sinuses - a young woman winces and grimaces in revulsion with every escalating noise. 3Com's solution is to go wireless: "Simple sets you free." Depictions of wireless freedom began in the mid-1990s with Sharp and MCI and became widespread in recent years in ads for computer and telecommunications companies - e.g., Winstar, Compaq, Intel, SBC, Microsoft and AT\&T. Intel illustrates its injunction to "unwire" by showing people dragging their desks and chairs just about to any venue - from the middle of a football field to the middle of a loading dock to the edge of a three-meter diving platform. One's work becomes spatially unbound. Indeed, a Winstar ad for its "Office.com" ("The new way to work") distributed computing service featured a jogging financial manager who has an idea for a new pricing model. He stops in his tracks and proceeds to work through the mathematical proof for the pricing model on the side of a dirty truck with his finger before rushing to a conveniently located Office.com outlet to send his idea back to the office.

In "Wireless Solutions for a Portable Planet," an Aether ad features a small startup company consisting of four twenty somethings riding around in their convertible. The narrative quickly suggests they are competing for a contract with a large - and smug - corporation. The semiotic binary is easy to follow: wireless, youthful startup in red convertible versus large, fixed, colorless corporate entity; and the winner is equally obvious. The ad is punctuated with an aggressive symbolization. Having just won this nameless and abstract, but apparently lucrative contract, the convertible drives up to a stretch limo version of the Hummer - says one of the women, "I thought we could use a bigger office."

But the same technological forces that promote flexibility, mobility and freedom, can also be used to discipline, monitor, enforce and control.

A 2000 Nextel ad speaks to this latter issue with a story about two corporate suits in Hong Kong. One man declares that what he loves about being in Hong Kong is that there is "no leash...no way for the office to keep tabs on you." At that moment his companion receives a phone call. When the wannabe slacker asks "what is that," his companion says "Nextel worldwide - works everywhere we do." The first man retorts, "Well that just means you're gonna have to work everywhere, Bob!" To which the second man replies, "Actually it means you do, I just got promoted, you work for me." As he snickers, we can almost feel the prison door slamming shut, but only for those who aren't savvy enough to use the most efficient communications technology - those who use it first, get promoted. First, the privilege of corporate work sets you free, then the technology catches up and there is nowhere to hide.[5]

\section{Stories of Technology, Gender \& Mobility in the New Economy}

By the late 1990's some ads hailed female executives, addressing questions of both success and obstacles on the climb up the corporate ladder. A 1999 Micron Electronics ad takes place in a corporate cube farm. In this ad promoting the high technology profile of Micron, a computer maker, the action is controlled by an angry young female employee who freezes the scene, grabs her boss's golf club and proceeds to smash through the old social relations of the workplace -- including an allusion to the "glass ceiling." Apparently, she is able to smash down old tyrants and obsolete technology, along with brittle old barriers and inefficiencies, because the new revolution in telecommunications and computing makes the prevailing ways of doing things anachronistic.

The scene opens with the hum of office noises (phones and office equipment) and a cyan-tinted shot of a large corporate office complex defined by partitioned cubicles spreading as far as the camera will let us see. It is business as usual as male executives move along the corridor, briefcases in hand. The camera cuts to a blond young woman inside a cubicle as she slams her hands down on her desk and pushes herself out of her chair. "I will not do this!" Her face is a study in frustration and anger, as she asserts her refusal to work under these conditions, and her refusal freezes all action in the office space. "I will not be a cog in a machine," she declares as she seizes a golf putter from the hands of a frozen executive (presumably her boss) who had been strolling through the office, club in hand, when our protagonist stopped time. She marches purposively across the room and swings viciously at a conventional computer monitor, smashing it as she begins delivering her manifesto: "I will not accept the obsolete!" Making the boss's golf club her assault weapon of choice symbolically captures, and reverses, the privilege of the 'old boy's club' that runs the corporate show.

"Keep your corporate ladder," she defiantly asserts as she takes another violent swing at what seems to be a ceiling panel, once again shattering it irreparably. Using the master's tool (golf club) to attack the notorious "glass ceiling" that keeps women from getting their just due in salaries or positions, certainly makes a vivid metaphor for 
'smashing the glass ceiling.' The reference to "empty mission statements" is a caustic swipe at faddish corporate public-relations lip-service regarding product excellence and respect for employee work satisfaction. By alluding to the flowery corporate rhetoric of mission statements, this Micron Electronics ad addresses the same cynical impulse targeted by Nike ads -- forget the talk, let's see you walk the walk. But this is hardly an anti-mission statement - despite its angry tone, it resonates with much of the rhetoric about corporate culture. Though the Micron Electronics ad represents an attack on a generic corporate workplace, representative mission statements and corporate philosophy weave together the issues condensed into symbolic form in the Micron ad. The buzzwords that predominate in statements of corporate philosophy include the "new rules," (e.g., open architecture, working outside the box, and non-hierarchical culture).

As she spits out her fury and her anger, she approaches her boss, still immobilized in time and place, and snarls directly into his face to, “Keep your empty mission statements. I will never play by the old rules again!" The boss's head then breaks and crumbles into pieces, his face cracking like a plaster mask from a Magritte painting. This image figuratively suggests a crumbling of his authority due to her defiance.

A male voiceover declares that "The rules of business have changed and Micron PC's featuring Intel Pentium II processors are the digital slingshots you need to win." The old boy's club is dead thanks to Intel and Micron technologies that ostensibly give voice to the refusal to acquiesce to alienated work in the archaic structures of your father's corporate organization.

Does technology allow a worker to rebel successfully against the capitalist impulse to transform her into "a $\operatorname{cog}$ in a machine?" How does the technology of semi-conductors blunt that impulse? Just how does her "digital slingshot" work? Though the ad explicitly names its computers using the Pentium II chips as "the digital slingshots you need to win," how does a digital mode of production pose contradictions for the hegemony of the corporate Goliath? This ad, nonetheless, heralds nothing less than a reordering of capitalist relations of production because of changes in the mode of production (technology). "New Rules. New Tools."

An allegory about power in the corporate workplace, this ad suggests a story about a revolution from below, in this case waged by a woman denied leading edge technology or her rightful place in the hierarchy of responsibility, discretion, power and rewards. It offers a cautionary tale of what happens when the rhizomatic wannabe is treated as human capital (a factor of production) and denied the opportunity to fully express herself in her work. Was this a story of empowerment, or a cautionary tale for corporate executives of what happens when a company doesn't keep current? Disregarding new technologies and their organizational implications can generate crises of morale, productivity, and even control. We are not sure whether one can build a new house with the Master's tools, but in this story, the Master's tool (the golf club) can be turned to tear down the walls, ceilings and power structures of his building, while the new tools apparently belong to 'everywoman.'

\section{Time Bind Mom - A Wireless Life in balance}

A 1998 AT\&T ad opens with scenes calculated to evoke the everydayness of home life, bringing forth the feel and texture of real interactions from the backstage area of daily family life. Hyperreal encoding in combination with a TV cartoon soundtrack playing in the background sets the interpretive tone for the story. A woman scrambles to finish getting dressed, putting on her makeup, and gathering together her portfolio materials for a meeting, while her three girls are variously engaged with breakfast. The oldest prepares eggs, while the baby plays with food containers from an open refrigerator door, and the four-year old disinterestedly spoons her cereal onto the table.

The oldest girl calls out: "Mom, I can't find my skates."

Mom calls back, "Look under the table," before adding a reminder about "No TV all day, remember?"

Daughter replies: "Our babysitter watches TV all day."

The mother-daughter exchange regarding TV watching rules is suggestive of their dynamic. The mother attempts to reinvoke her rule about restricting television viewing while she is gone. Her daughter's rejoinder challenges the fairness of a rule that seems arbitrary (and unenforceable) insofar as the babysitter disregards it. As she makes her case, Mom opens the door to reveal the babysitter who has just been 'outed' for breaking Mom's no-TV rule. Mom is too hurried to concern herself with this breach. Viewers are apt to note the blank look on the babysitter's face. This 'teenager look' lends a note of authenticity to the ad, and is an important means of 'hailing' the intended audience who may already recognize similar looks from their own experiences. These are the landscapes of daily life. Amidst tricycles and bicycles strewn along the hallway, the babysitter leans against the wall, listening, but uninvolved, while 
the baby wanders away from the refrigerator, still undressed. By allowing the mundane to remain mundane, a kind of visible background noise captures the everydayness that frames these relationships. The ensuing dialogue however cuts to the heart of their drama.

Oldest daughter: "Mom, why do you always have to go to work?"

Mom: "It's called food, video, skates..."

Oldest daughter: "Can we go to the beach?"

Mom: "Not today honey, I've got a meeting with a very important client."

Four-year old daughter asks plaintively: "Mom, when can I be a client?" and then rests her chin on her hands to signify

sadness.

The child's question sends an emotional dagger of guilt through Mom. Her facial expression reflects the tension she feels as she puzzles over what to do. Here is the classic tradeoff. A parent works longer hours away from the family to provide for her children (so they can have food, video, skates) but then regrets the time not spent with them. The advertiser has left open interpretive room as to whether this woman parents alone or not. We think she is a single mom. Certainly, women who try to raise children and compete successfully in the managerial ranks of the corporate world face a double whammy, doing double duty in both spheres.

While Mom declines her daughter's initial request that they go to the beach due to her job commitments, the ensuing question from her younger daughter about "when can I be a client?" prompts a guilt-induced reassessment, as she realizes she has given her "client" a higher priority than her "daughter." Her guilt feelings are heightened by her children's sad, pleading looks. She is impelled to consider another way of reconciling the conflicting demands she is being asked to meet. We see her eye catch sight of the cell phone upon the counter -- the solution, of course, lies in her AT\&T cell phone! She announces that "You have five minutes to get ready for the beach or I'm going without you," and the girls scream with glee as Cyndi Lauper sings "Girls just wanna have fun." This ad speaks directly to working mothers about how to reconcile the tensions in their lives -- how to be loving, and available, parents to their children and still fulfill their career duties and aspirations?

AT\&T presents the issue in this sympathetic narrative, and then offers a way of transcending this guilt. Career women can, if they are agile of mind and spirit (and who wouldn't want to be?), meet everyone's expectations while harmonizing the interaction of work life and family life. They can accomplish this if they choose the appropriate brand of technology. In the reunification of self, family, and business, AT\&T portrays its telecommunications technology as an instrument of liberation, literally an instrument that frees her up to be in one place (the beach with her laughing kids), while also inhabiting another space (the phone call/meeting with her client). The conflict between work and home/family obligations has been vanquished when Mom answers her phone on the beach and here fouryear old daughter screams out, “Hey, everybody, it's time for the meeting!” It’s a grand new world, where Mom's can have personal and professional happiness because as the tagline declares: "AT\&T -- It's all within your reach."

This ad amplifies an issue raised by Arlie Russell Hochschild in The Time Bind: When Work Becomes Home and Home Becomes Work (1998). Not just working women, but working fathers as well, are prone to feel guilt about being away from their children, but they also feel tension about being away from their jobs, or letting down an employer. The AT\&T ad ostensibly addresses the structural conflict that Juliet Schor refers to as the "time squeeze." But if we superimpose Hochschild's interpretation over this ad, we might see the guilt relationship in another way as well.

Middle class culture claims to prioritize family above all else in our lives. So why then does it seem to be so difficult to find a balance between work and family life? Hochschild thinks the problem might be that many of us are more ambivalent than we would like to openly admit about spending time with family. Why do employees experience a "time squeeze"? Until recently, corporations presumed a world where men's careers mattered and women stayed home to keep house and raise kids. But that world has begun to change, and if the corporation Hochschild studied is representative, the time squeeze is no longer due solely to the company's failure to appreciate the squeeze placed on working women. Even though the corporation she studied had flexible hours (including job-sharing options and part-time arrangements) and family-friendly policies, she found that both ambitious employees seeking promotions, as well as lower level, and hence more easily replaceable workers, tend not to take advantage of these options. The ambitious understand that time spent away from work can diminish their chances of advancement in rank and salary. At the other end of the job spectrum, less skilled workers have job security fears that are not entirely assuaged by the firm's policies.

Working parents in dual-career families have been spending more and more time at work - not simply because 
they face growing work loads, or even because they're afraid of losing their jobs (though certainly in a downsizing environment that fear cannot be ruled out). Hochschild suggests some are fleeing the pressures and uncertainties of home life and escaping to work, where they can feel in control, or at the least avoid the emotional dramas played out at home. Hochschild reports that though they later tend to feel guilt about this method of avoidance, working parents sometimes prefer the social side of the office to the boredom of household chores, to quarreling or whining kids, or to confronting unresolved emotional conflicts at home.

Hochschild sees the "time bind" as a chain of relationships. Corporate employees may feel a need to spend more hours at work to support their families. This, in turn, prompts increased stress at home, which many parents react to by finding reasons to spend still more time at work to escape the tension at home. These self-contradictory relations contribute to what Hochschild terms the "third shift" -- the time parents spend repairing the damage generated by their compulsion to work. This dynamic was probably not new to the 1990s, but rather endemic to the social and cultural contradictions generated by middle class socialization practices that demand both a commitment to selfachievement and an obligation to the goals of familial intimacy. These don't necessarily fit together, and Hochschild calls attention to what many middle class ideologues would prefer to repress: employees frequently choose to work because they find it more rewarding than time spent in the emotionally messy arena of family life.

\section{Going Up: Networked Mobility in the Flat Hierarchy}

A 1998 AT\&T ad tells a story about the speed at which business must operate today if it is to be competitive at the highest levels. This story about using communications technology to fine tune organizational efficiency is told via a success story about the career fast track in an era of distributed organizations.

Matt, a young executive hoping to climb the ladder of success, enters an elevator occupied by a bike messenger. At the next elevator stop a female supervisor/manager enters the elevator, saying "Matt, got your e-mail. Vancouver. Genius." The song, "I want to take you higher," by Sly and the Family Stone kicks in as she tells him that she has already begun the process of moving this idea through a distributed, and synchronized, division of labor as the screen cuts to a shot of a computer screen with the label "Linking Company Offices." On the computer screen appears an organizational flow chart and pop-up images of managers in the Seattle and Portland offices.

Another male manager enters the elevator at the next floor and cheerily informs Matt about the progress his idea is making through the organization. "Hey Matt, idea's a hit in the Northwest. Expect love letters. I've got purchasing checking suppliers." Reinforcing these points, we see in visual counterpoint the diagrammatic network connections being made across the network and a computer software application "linking with suppliers." It seems that everyone in this organization knows instantaneously of Matt's idea and its movement. The celebration continues as colleagues greet him on successive elevator stops, with comments that suggest successive steps in the process of vetting the idea. "Specs sounded pretty Matt." "Legal's putting it through the mill." Confirmation that Matt's career is on the ascent comes when a senior member of the firm referred to as "Counselor," greets Matt with a casually bemused smile, "Looking a little golden this morning son."

As he reaches the ground floor and starts to exit, a young woman stops him, "uh uh, you're wanted up top. Client briefing. Your Vancouver idea." As the elevator carries him toward his new status, the young executive turns and exchanges glances with the bike messenger. His success is acknowledged by an approving nod from a bike messenger who exudes quiet subcultural coolness and confidence. Matt's bright idea has been recognized and he is on the rise. The system works when AT\&T technology is chosen to electronically link all aspects of its business efficiently with suppliers and customers, thus streamlining organizational decision-making. In the landscapes of the new, networked capitalism, the best ideas win out because the ultimate arbiter is speed to market. The announcer inquires, "Want to take your business to the next level?" while from below, we watch as the elevator ascends upward through the elevator shaft into the bright light of corporate salvation.

The story is told through a series of juxtapositions. As a narrative device, the elevator might seem better suited to an era of vertically integrated bureaucratic organizations, but here it is used to tell a story about a geographically dispersed global corporation that has reshaped itself via the adoption of AT\&T's network communication systems to span geography and division of labor. As a spatial metaphor, the image of the elevator suggests vertical movement through the space of the built environment. Here the elevator lends semiotic weight to multiple signifying agendas. It is not simply an elevator, but a vintage elevator marked by art deco aesthetics that signal a golden age of business in the architectural era of high modernism. The bas-relief bronze motifs are reminiscent of the aesthetic of Metropolis, suggestive of an era of material substance. Digital innovation does not appear to imperil the bourgeois heritage of 
business, nor does it require the negation of classic infrastructure. The elevator's mechanical functionality is visually highlighted and juxtaposed with the digital flows of information, making it a convenient measure of the rapidity with which ideas move in the new organization. From new idea to implementation in the length of time it takes him to ride the elevator down. Moreover, the buttons of the elevator still offer a familiar indexical metric of individual mobility, going to the 50th floor is the ultimate indicator of successfully making it to the top.

Images of organizational flow charts and screens of software functionality are intercut into the elevator narrative to illustrate how network connectivity works in a distributed work environment. The commodity premise here is the linked organization -- the coordination of functions and decision-making when employees are dispersed geographically in large global firms. This implies a business organization with relatively few bureaucratic levels of decision-making to go through. While this aims to demonstrate the virtues of a "flat" organization, the ad still locates authority and reward structure at the top. And if instantaneity of communications yields transparency of decisionmaking, it does by keeping authority visually absent yet panoptic.

And yet the cultural authority that affirms the fairness and rationality of the narrative outcome comes from below - from the bike messenger. This twist is worth considering. The other primary figure in this story is the bike messenger, though he never utters a word. At ad's end his nod of approval is crucial to recognizing and validating the achievement of the young executive on the rise. In the post-Fordist urban political economy the bike courier offers a flexible means of circulating and delivering small batches of information as corporations downsize, outsource and spatially decentralize. And yet, like all other elements of a post-Fordist universe, the courier is disposable, replaceable, and expendable. The significance of his look of approval is contingent on our acceptance of his symbolic presence as the antithesis of corporate culture - a hipster with long hair, a goatee and tinted shades who knowingly observes, but does not participate. In the folklore of postmodern urban spaces, the bike courier has been constructed as a nonconformist outsider - a risk-taking renegade who refuses to be tamed by the rules of wage labor; the physical nature of their work permits them to symbolize freedom. Unbound by chains of corporate regimens, his look affirms that unconventional and innovative thinking will be recognized and adopted where it works.

\title{
Manufacturing Labor in Postmodern Discourse
}

With the exception of automobile and truck ads, manufacturing labor has continued to disappear from the landscape of work. The infrequency of traditional factory imagery corresponds to the steady loss of manufacturing jobs in the United States over recent decades. Sometimes indistinguishable from rural labor, such representations are nevertheless more common than farmers who are becoming extinct across the advertising landscape. By contrast, during the 1970s and 1980s, though their numbers diminished rapidly, the farmer remained an icon for all the virtues of American workers. Nostalgic representations of farmers and ranchers have not completely departed the scene; it's just that circa 2000, the unadorned salt-of-the-earth work ethic now competes with another rationale for introducing the image of a farmer or rancher - to demonstrate how advanced technologies can sustain an otherwise declining way of life by making it more efficient. This is the story told by Microsoft about the small ranch-oriented, rural town of Lusk, Wyoming where enlightened citizens are adopting advanced communications technologies to preserve a bucolic and romanticized country way of living. Farm communities have suffered enormously in recent years - hit hard by the epidemic of bankruptcies amongst small farmers, the loss of jobs in rural industries, the erosion of tax bases, dismal schools, and the hemorrhaging of the best and brightest to sites of greater opportunity.

\begin{abstract}
Male voiceover: “This is Lusk, Wyoming. Cows outnumber people here 100 to 1 . The thing that isn't apparent about Lusk is it's wired. Lusk has strung fiber optic cable for the future of high speed internet. The schools have 320 computers for 500 kids. Home businesses and PCs are common. Why? They're practical people. They want to talk to the outside world using technology. They want to save their ranches with technology. They want to talk to the kids who've left and keep more kids from leaving by having the technology. They want to save their small town and keep it exactly the way it is, and they're using everything they can think of to do that. Technology is a tool. Software is a tool. These are the dreams it's made for, and that's why we make it."
\end{abstract}

The Microsoft narrative is interesting insofar as it warps the Marxian model of social change. Forget the contradictions between the social relations of production and the mode of production - we now live in the era of re-engineering, proclaims Microsoft. Not just companies can be re-engineered, now communities can be too. Want to hold on to a form of social and cultural life that is no longer consonant with the macro political economic forces 
of the day, then invest in the very technology that threatens to engulf you. Or perhaps, we should read the Microsoft narrative in the opposite direction, as a shrewd neo-Marxian assessment of what can happen when new technologies are leveraged to take advantage of emergent political-economic contradictions.

Factories are few and far between in corporate ads as sites of production especially when compared with other sites of value production - scenes of corporate headquarters or corporate research labs. The only consistency of factory representation occurs in corporate automaker ads where nearly identical scenes of capital-intensive production facilities appear in ads for GM, Saturn, Ford, Mercedes, Acura, Honda, Hyundai and Toyota. In these ads, automated computer systems control precision technologies that regulate the production process, while autoworkers are given cameo appearances. Spotless factories gleam and shine like the cars they produce, the site for a graceful ballet of meticulously choreographed movements. Production is turned into an aesthetic -- a fireworks display of sparks explicitly proclaimed as art and tended by occasional workers who display the exactitude of technicians or the sensitivity of artists. As might be predicted, these ads are more about the manufacture of desire than the manufacture of industrial goods.

Ads for GM and Saturn actually stress their "partnership" with the UAW as it speaks both to their general profile of corporate citizenship and to questions of quality production. Toyota ads celebrate their new investments in the US with similar ads that include close-up shots of solemn autoworkers (in this case non-union) devoted to their tasks in the assembly of small trucks. One would never guess from these images that such capital-intensive vehicle assembly plants have deskilled this work, or that these men and women are laboring for relatively less than their historical predecessors. In fact, the whole tenor of the Toyota campaign is to demonstrate that foreign capital in the United States creates new jobs $(200,000)$ and sustains the nostalgic image of the American landscape.

The bottom left image from Saturn (1995) represents the sincerity of unalienated labor, and a nostalgia for a past mode of labor made better by enlightened corporate capital. The bottom right image from Datek Online (2000) represents the death of industrial labor. Whereas Saturn endorsed the autonomy of labor as the best way of serving consumer interests, Datek depicts the interests of labor as antagonistic to consumer interests which are better served by the electronic annihilation of the industrial model.

As a productive force, labor has lost its Promethean connotations, supplanted by smiley-faced service symbols (see Wal-Mart), computer controlled robotics, or numbed apparitions that impassively function according to script. The face of labor as heroic - the image of larger-than-life labor capable of conquering nature (and enshrined in the imagery of socialist realism) - has retreated from the site of production. Instead, the heroic profile of labor is delimited to images that hail a masculine demographic that buys pickup trucks. Ford Truck ads hail the traditional heavy labor of hardhats, construction workers, railroad workers, machine repair, welding, and men who tow or demolish - all jobs that depend on muscle and calloused hands. Close-up shots of unsmiling, unblinking, weathered faces speak to the pride, integrity and toughness of such labor and give the impression that such men take no orders or directives from any boss. The men who inhabit the mythical landscape of "Ford Country" are integrated racially and geographically, just as much rural as deindustrialized. The space of production for this portion of the working class, given the fact that the ads are for trucks, is primarily outdoors.

Though working class jobs associated with the previous mode of industrial labor have generally disappeared, the imagery of an industrial labor force and the conditions associated with it persist on the margins, usually as a pejorative. Industrial imagery is caricatured in Datek Online ads to create the semiotic opposite to the instantaneous electronic circuitry that Datek claims to operate. The stock trade at competing online brokers is conceptualized as a material paper object received via a mechanical chute as an "incoming order" and then processed. An archaic assembly line follows a tedious subdivision of tasks so that "your order to buy or sell a stock simply gets handed from one middle man to the next." When the lunch whistle blows and everyone files out of the room, we are prompted to realize just how slow and laborious this process is compared to the instantaneity that Datek associates with its own electronic circuits. The gray model of industrial organization is presented as antiquated and outmoded, not just because of the industrial model, but because that model relied on alienated labor to execute tasks. Datek claims to offer superior efficiency by eliminating mechanically robotic human labor mired in stagnant, non-productive social customs and routines.

\section{| Outsourcing the Labor Search}

A central tenet of flexible accumulation is the need to adjust labor supply to the circumstances at hand. The 
effort to reduce fixed labor costs and the long term commitments of health care benefits has led to abandoning manufacturing plants in the United States as well as the movement towards using temporary labor for light manufacturing as well as office work. Since the inception of capitalism, labor has been a commodity, but with the dotcom frenzy of the late 1990s came the invention of the online employment agency. Such firms sought a niche in the logic of corporate concentration and globalization - they delocalized labor markets, and offered to outsource the organization, coordination and management of the hiring process so that client firms can outsource their labor requirements as well as downsizing their own in-house personnel staffs.

Companies that advertise in this space may seek to appeal to employers or potential employees. The pitch varies accordingly. When addressing employers the stress is more likely on recruitment issues -- on managing an orderly and efficient process that identifies the appropriate skills while assuring a dependable and reliable supply of labor when needed. While this is generally a deadly serious matter for employers, the ads frequently lean toward a more humorous tone of voice. Accountemps promotes its expertise in "specialized financial staffing" by making fun of a whiney male executive who is outflanked by a more savvy female executive who knows who to call to get the job done. EDS advertises its experience in IT outsourcing by illustrating the perils of grabbing homeless people off the street to fill temporary IT staffing needs. Or when Hotjobs.com wants to impress upon employers the scientific precision of their panoptic sorting process in "pinpointing" the most appropriate job candidates, they opt to buffer the Taylorism of their pitch by sewing together a stylized pastiche of archived training film footage.

Woman's voiceover: "Look potential in the eye. Searching for job candidates that measure up? Let us assist. The hot jobs
database let's you gather and inspect only the best candidates. Our easy to use technology allows you to pinpoint the people
with precisely the training you need, and enables you to manage the entire hiring process. You can even update and refresh
job postings as your needs change. So if you're looking to enlist the best Call 1.877.hot.jobs"

When it comes to supplying manual labor, however, the visual tone becomes more sunny and sincere. Labor Ready is a multinational sourcer of unskilled labor. Reflecting their point that "Not all temps type" this ad constructs an orchestrated montage of energetic working images that include janitorial services, catering, loading and unloading, unskilled construction, waste hauling and disposal, maid service, landscaping, window washing, and agricultural field labor.

Male voiceover: "No matter what your business, if you need to move it, clean it, cater it, build it up or tear it down, you can use Labor Ready temporary labor. Just call 1-800-24-LABOR or order on line at laborready.com and you'll get all the help you need. You can find good help these days. "Labor Ready. Dependable Temporary Labor."

The Labor Ready website is more direct about what they offer. "We help companies turn on-demand labor into a strategic advantage. No matter what the job, no matter how many extra hands you need, our team can show you how deploying the right workers can cut costs, increase efficiency, expand revenue opportunities, and make your life easier."

The appeal to potential job candidates is about finding a future that is not alienated, by finding a meaningful job worthy of you! As labor markets become corporatized and globalized, these ads depict the negotiation of labor markets as hostile and perilous spaces that few can navigate without the aid of a branded online site to clear a path. Agencies that offer to create a competitive advantage in labor markets include the largest online employment agencies -- Monster.com, Hotjobs.com, Thingamajob, and K-Force -- and they seek to signify the limitations imposed by boring and alienating jobs, as well as opportunities for more satisfying lives. In this dotcom market niche it was imperative that ads differentiate the brand identity of the firm, so the ways in which they represented alienation varied substantially.

An ad for Hotjobs.com reprises the vision of industrial work as equivalent to being held in a Soviet-era gulag work camp. The grim surroundings of factory work and conveyor belts are amplified by a melancholic song about dreams of rainbows ("Rainbows are visions, but only illusions.") that ends with the vague hope that someday there will be a better life.

The advertising for Thingamajob presents a critique of work in the corporate political economy. While the voiceover lays out a critique of bureaucratic rationalization and commodification in corporate labor markets, the visual representations offer a bleak vision reminiscent of the Apple Macintosh 1984 ad amid the aesthetic of the movie, Brazil.

Female voiceover: "You are not a number 


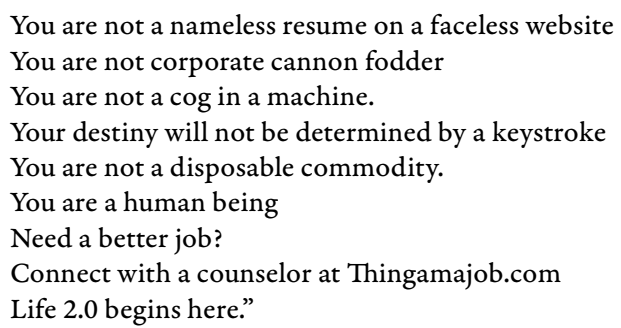

Shaved heads tattooed with barcodes signify the objectification of workers in scenes that create a grimly standardized vision of being a nameless, faceless cog. Movements are regimented -- strictly controlled, over-disciplined and standardized -- and the forbidding space in which they move is without color or any emotional vibrancy. As the manifesto builds to the declaration that "you are a human being" one shaved head break ranks. In the Hotjobs.com and Thingamajob.com ads the existing work environment is presented as a deformation of the opportunity to have one's personality realized through the activity of work. These ads, the first in the industrial sector and the second in the office sector, do not suggest some sort of structural revolution that will yield unalienated jobs, rather they offer a lukewarm hope (illusion) that something better will come along for the isolated individual.

If the work environment looks inhospitable, so too does the job search process until one secures the assistance of trained specialists. K-force.com, a "specialty staffing firm" that concentrates on matching the staffing needs of Fortune 100 firms with the resumes of professionals seeking employment in information technology, finance and accounting, human resources, legal, and engineering, depicts a perilous Blade Runner image of internet job sites patrolled by con artists, hustlers, and duplicitous hucksters ready to take advantage of you. Step through a door to your future job, and you just might find yourself falling, nightmare like, to a barren desert floor. Another ad for kforce.com boosts the fear factor as it ominously depicts the competition for jobs ("It's you against him, against her, and who knows who else? All going for the same job. So what's going to set you apart?') in a space where you don't know your competition, in a space where employers simply see faceless resumes.

In the first k-force ad, the street hustler's rap is "I got hot jobs, cool jobs, jobs that are absolute monsters." This a symbolic swipe at its better-known competitor, monster.com. Though one can infer references to the alienation of labor from monster.com's ads, Monster offers the cheeriest and most optimistic appraisal of what is possible in the current job environment. While their initial ads offered cynical assessments of work as a necessary evil, their more recent ads are narratives of encouragement and celebrations of the possibilities for achieving self-realization.

Male voiceover: “"'Don't think of your next job as your next job

Think of it as a long term life enhancement upgrade."

It is curious however, that like hotjobs.com, monster.com opts to invoke software metaphors to describe the relationship between a new job and one's life chances. Each ad uses the metaphor to give a positive spin. And the metaphor seems apt enough insofar as these are online employment agencies, but the metaphor is not unequivocal as it frames the individual's life history. Software version upgrades are notoriously short-lived, certainly never a promise of long term happiness; they are always subject to obsolescence. Life 2.0 is inherently unstable as a "life enhancement upgrade."

\section{| The Missing World Poor}

The great disparity in wealth that structures global inequality vanishes with nary a trace in these ads. As might be expected, television ads contain few references to the world's poor. Not only are the material conditions of poverty kept out of sight in advertising, even the relationship as such is denied by how the ads frame their subjects. The structures of inequality vanish, as do all modes of exploitation. Ads insulate elites from nonelites, and keep wealthy individuals in safe havens. These elites travel through the space of non-places, spaces that are generally depicted as desirable because they are devoid of social contact. In the social world as refracted through the lens of advertising, elites and poor may be even more segregated than in everyday life. Occasionally, very occasionally, an ad slips up and reveals the relational terms of this separation as in a 1998 ad for Korean Air that juxtaposed idealized images 
of field laborers against the luxury of their first class accomodations where clients are seen enjoying the fine foods made from the crops just picked.

When the poor are represented, they are not usually depicted as active subjects, but as tragic figures aided by the benevolence of capital, usually in the form of charity. Abstracted from conditions of poverty, the poor in developing countries are sometimes presented as the beneficiaries of corporate largess and scientific (medical) research. Neither market forces nor corporate capital appear to contribute to poverty in any systematic way. There is a curious absence of neoliberal evangelism in these ads - no moralizing about how market forces will save the poor from corrupt regimes. The landscapes of globalization presented here bear no signs of structural adjustment austerity programs and the harm they inflict on local populations in an effort to stabilize currencies and attract foreign capital. There are no hints of maquiladora zones, nor wide-angle shots of ever expanding urban slums, no global circuits of prostitution, no civil strife, no environmental destruction. Instead corporate brands (e.g., Philip Morris, American Express) represent themselves as the conscience of the world, devoted where necessary to enhancing the lives of the poor whose circumstances remain unexplained.

Truly this is a simulacra, for it has no original. The referent is imaginary. Even the measures of conservative organizations such as the World Bank, flawed as they are, indicate that of the 4.8 billion people living in the countries of the developing world in 2003, 1.2 billion existed in extreme poverty (defined by the World Bank as living on $\$ 1$ per day or less) and 2.8 billion live in poverty ( $\$ 2$ a day). Poverty of this magnitude breeds disease, malnutrition, starvation, illiteracy, and overpopulation, and these consequences are amplified by the severity of the gap between rich and poor. In 2003 , the richest fifth of the world's population received $85 \%$ of the total world income, while the poorest fifth received just $1.4 \%$ of the global income.” (http://www.infoplease.com/ipa/A0908762.html)

\section{Portrtaits of Third World Poverty}

Inhabitants of the third and fourth worlds -- those places on the planet that have been systematically underdeveloped, thanks to the legacy of colonialism, capitalist imperialism, and now globalization -- do occasionally make an appearance in corporate ads. Bringing a smile to Africans is the subject of a one-minute 1998 Crest ad that stresses the importance of educating the poor in developing nations about dental hygiene. Shot in Zimbabwe, the ad offers testimony about how well this humanitarian strategy is working. Rotting teeth have long been an easily identifiable signifier of poverty, and while a big bright smile might not erase poverty, it does seem to erase one of poverty's most painful and ugly markers.

The Crest ad is unusual in that it identifies the geographical and social location of its subjects, unlike the more generically abstracted images of third world peoples, such as the silhouetted image of women carrying baskets on their heads (See Figure 46). Where access to the public sphere is through television advertising, even non-profit organizations compete with similar discursive abstractions.

For example, an ad for Children International introduced an undernourished, poorly clothed child who is named 'Michelle.' The naming process emotionalizes her, encouraging viewers to connect to her plight, so that the narrator, Walter Coppage, can make a plea for donations to help this girl and the other children pictured. The children don't smile, play, or run. Their saddened faces and tattered clothing draw attention to a body language of helplessness. Often depicted clinging to an adult or some dull inanimate object, they have no energy. Colorless, lifeless slums in the backgrounds remain unidentified - they simply permit us to locate the world's poor 'overseas' in grim zones of poverty apparently unconnected to any political economic forces or social relations that structurally premise their poverty.

An emotionally powerful, photorealist representation of poverty appears in an advocacy ad by Mt. Carmel Baptist Church. Combining an African-American gospel song with images of agony and suffering produces a heartrending montage of gaunt and starving children, children with missing limbs, crippled, alone, and in tears. Touching as this ad is, it remains an exercise in universal humanism that privileges an idealist response - "We got to love to get along in this world." By decontextualizing suffering, by taking it out of its historical conditions, the horror of these images invites not a political solution, nor an economic solution, but a spiritual response linked to donations that might stay the ravages of unbearable suffering for one more moment, one more day.

A majority of images of third world people in television ads are children. This fits nicely with allusions to future transcendence. But the corporate imagery differs from the gaunt representations that one sees in ads for charities seeking to stave off malnutrition, disease and death among starving and mutilated children. Whereas portraits of new global elites include children as subjects (love objects) who motivate the new elite, portraits of the poor visually and 
narratively focus on children's faces while marginalizing adults to support functions as teachers or nurses.

\section{Corporate Narratives of Poverty}

The few corporate brands that address poverty also rely heavily on images of children and the elderly - for these are the categories of the deserving poor. The American Express 'Charge against Hunger' campaign ran during the Christmas shopping season for several years. The children in this campaign are smiling and happy thanks to American Express. This is a seasonal fix to the problem of hunger. Though this program was aimed at the United States the background music has an African tint. It is upbeat and communal, inviting the privatized viewer to become part of a wider human community. Ironically, entrance into this community was accomplished by going to the local mall and accruing credit card debt. When corporations venture into the imagery of poverty, signifiers of possibility and promise replace the signifiers of hopelessness. Sullen faces turn to smiles; inactivity becomes play; slums are replaced by communities. Numbers appear on the screen to offer empirical confirmation that the American Express campaign works. In a class-based society, the American Express campaign reasons that hunger can be reduced if the more affluent simply buy more commodities. Consumers don't have to give up disposable income in the form of taxes to support social programs. It's a win/win situation. Moreover, there is no sense that American Express is simply donating a small portion of its profits drawn from high interest rates attached to commodity desire and subsequent overconsumption. [6] We don't see any statistics on corporate profits or on the cost of this public relations campaign. Unfortunately, the State and its programs ('welfare') don't advertise this way. Imagine shots of a happy family cashing in their food stamps.

In a series of images linking childhood with future potential, Cargill takes the poverty out of being poor under the banner of universal humanism. Cargill succinctly iterates a variant on the rights of man - here are the rights of children. Every child is born, not so much equal as special. Here then is a noble vision - nourish "every [hungry] child on this planet" and imagine what accomplishments will be made by individuals contributing to the greater good. Here is a curious vision of the capitalist system, the inverse of capitalist rationalization - the goal of commodification is only a means to a greater end - feeding the children of the world and watching billions of flowers grow.

Female voiceover: "Every person on this planet, no matter how big or small - is filled with potential. Every mind, whether it exists in wealth or poverty has the ability to think great thoughts. Every idea, no matter who it comes from is full of possibilities. Cargill believes this potential must be nourished because the better we are fed the more we hunger to achieve.:

The scene keyed to the word "poverty" shows a child next to what appears to be an abandoned British factory. Yet, the aesthetic devices (decontextualization, choral music, portraiture associated with grandeur) of the ad in conjunction with the uplifting narration dissolves the hardship of poverty by equating it with formally equal scenes of children from around the planet. Though categories of social class, nationality, gender, and ethnicity are visually evoked, they are leveled by the overarching categories of "every person" and "every mind." Cargill celebrates universal humanism by situating every child as a singular subject on its own scape of global cultural geography. Cargill presents itself as a corporation committed to feeding the children of the world while the imagery connotes a healthy world in which progress and achievement are ongoing endeavors.

Like the Cargill ad, a Biotechnology industry ad aired in 2001, sponsored by the Council for Biotechnology Information, sutures together a smooth montage of scenes of that alternate between the poor with the privileged, between global North and South set against a soundtrack of airy and optimistic music. The ad opens with a biotechnology researcher explaining how "golden rice" containing beta-carotene "can prevent blindness in millions of the world's children." While biotechnology offers the first world cures for cancer, it is in agriculture that "biotechnology is providing solutions that are improving lives today and could improve our world tomorrow."

For the moment, we want to dwell on the concluding image of the montage -- a Vietnamese woman holding her child, stands posed for the camera in a farm field -- behind her are other peasants/field workers. She steps forward, while behind her the other faces remain hidden under the broad-brimmed hats they wear. They are all gently stooped over at their labor. But this remains abstract labor -- it is the pose of labor rather than the labor itself. This depiction plays on our longstanding stereotypes of Asian peasants bent over in rice fields. Stoop labor meets glamour photography. Indeed, the photographic codes seem to cancel out connotations of either coerced labor or the grinding poverty associated with this kind of field labor.

The same ideal-typical representation of third world peasantry appears in a scene from Boeing's 2001 ad campaign. Is this the poster-girl of the world poor and their future transcendence within a world of capitalist 
technologies? Why do capitalist corporations that have pinned their futures to the growth of 'high technology' choose this image of field laborers to depict their corporate presence in the world? The woman appears to possess a quiet dignity, and may even be seen as exuding a confidence that the future belongs to herself and her child. Her position in the montage follows immediately after scenes of a young middle class, white American girl who has survived cancer and is once again happily playing softball. Poverty is no more visible in the Asian agricultural fields than in the middle class suburb. And neither seems unhealthy. The female voiceover frames the meaning of the suburban scene as an illustration of how biotechnology research has produced discoveries "that are improving lives today." As the camera transitions to the frame of the Asian mother and daughter portrait, the voiceover continues "and could improve our world, tomorrow." One wonders however if that brighter tomorrow will be a function of changing conditions of labor, or if the biotechnology industry alone can abolish the consequences of poverty, disease and malnourishment?

Dominated by images of women and children the poor are represented as passive agents to be acted upon rather than as actors themselves. They have no voice. They are spoken for. And when corporate capital acts upon the poor, it is to the benefit of everyone. It produces golden rice, media classrooms, better agricultural products, new markets, healthier bodies and sharper minds. No form of resistance is visible, because like everywhere else in these landscapes, power and authority have been put to rest.

How do images of third world people fit into any conception of capitalist relations of production? For the most part, we have seen that the poor are represented as an accident -an act of god, or misfortune, or corrupt leadership. Though it hardly seems possible in an era defined by globalization, third world peoples appear even less involved in systems of production than do those in the first world in the representations of corporate advertising. We have seen that political-economic forces are never shown in relation to social problems such as lack of basic needs -- food, shelter, and medical care - but they are also repressed in relation to production. The reasons are obvious - there would be steep legitimation costs to pay if sweatshops, child labor, migrant field labor, shanty towns, barrios and slums appeared in proportion to their frequency in the system of commodity chains that shape global capitalism.

There are momentary exceptions. We have elsewhere discussed the FedEx representation of global just-in-time manufacturing in which disciplined squads of South Asian workers show up at otherwise quiet factory sites when they are needed to fill a European order. Fleeting images of third world youth, minus poverty, appear in montages for tech giants like Cisco, SAP, GE, IBM, and Microsoft. Such ads see third world youth not simply as future consumers but as part of a future global labor force that has been trained and educated. In recent years, oil companies such as the combined ChevronTexaco have quietly acknowledged that their previous approaches to energy extraction may have mismanaged the environment and exploited third world peoples. But that has all changed, because now, "Working together, we're developing energy faster. Developing people faster. And accelerating prosperity for all of us. Chevron'Texaco. Turning partnership into energy." Like the Biotechnology and Boeing ads, Otherness here is accorded a poised dignity -- in fact these ads narrate the visual transcendence of poverty in the developing world, thanks to technology, investment and "partnership."

\section{| Posting the Contradictions}

Our survey of how corporate advertising represents the social relations of production circa the millennium has unavoidably passed over various relevant aspects of these representations. One significant omission concerns representations of retirement. So many ads speak to the social relations of retirement that a full discussion will require more space than we can allot here. And we would have liked to address what might be called the "human capital" ads that appear for governmental units such as Michigan, Pennsylvania, Ohio, Korea, Ontario and others as they vie to recruit investment capital to their regions.

As we strain to summarize the representational patterns in 2,065 TV ads available to us for this study, we cannot avoid the self-contradictory character of this discourse. The very same ads that seek to deny the conditions of class also fantasize about the pleasures of privilege; the same ads that paint a utopian moment of retirement unconstrained by either scarcity or the performance principle also acknowledge that capitalist work relations are essentially a constraint on human potentialities; the same ads that betoken freedom and flexibility in new wireless electronic technologies also treat it as a necessary leash.

Taken collectively these ads make it difficult to conceive of social relations outside of the market mechanism. 
And yet, conflictual market relations disappear from view. Generalized markets seem to float in the ether, without need for laws or authorities to enforce rules. In fact, one can scarcely imagine any market in the world that is as purely self-regulating as the electronic markets represented in these ads. While the ads glory in the supremacy of open markets, they are not so forthcoming about the nature of capitalism. Capitalism mostly lingers in the shadows, an absent presence that shapes everything, but miraculously leaves no imprint of its grip.

Corporations utilize advertising discourses to legitimize their practices by naturalizing and universalizing the social relations produced by capitalist economic formations, without actually dwelling on either the capitalist part or the unequal relations. These discourses about markets and technologies coupled with an absence of national boundaries or state institutions, leave the impression that in an ostensibly post-Fordist network economy, corporations provide the conceptual infrastructure that holds together, and gives order to, the networks of production, distribution, consumption and reproduction that constitute civil society.

It will surprise no one that consumptive possibilities rather than production relations are the primary focus of advertising. The material production of commodities in factories, in workshops or on assembly lines is mostly absent. When manufacturing scenes do appear, computer-directed technologies seem to autonomously churn out finished goods on their own. We can confirm that compared with twenty years ago, there has been a decisive shift from scenes of farmers, manual labor, blue collar labor and even generic white collar labor, in favor of scenes of people clustered in small work groups working at computer monitors, in open architecture environments, and without the presence of external authority. Commodities mostly appear in transit, highlighting the importance of commodity chains and the transportation, communications and distribution networks speeding packages and packets this way and that across the universe. Labor generally shows up only in its finished product, such that living labor has no cultural power other than the romance of the individual faces isolated on screen, or in the magic of the branded totems that now carry the fetish traces of the ghosts of labor.

Adopting the landscape metaphor for our project has compelled us to reconsider whether or not these representations reflect changes 'out there' in some political economic reality? Do they disguise, distort or falsify fundamental changes in the relations of production? Does Louis Althusser's (1971:155) formulation concerning the relationship between ideology and the media apparatus still hold? "What is represented in ideology is...not the system of real relations which govern the existence of individuals, but the imaginary relation of these individuals to the real relations in which they live." Traditionally, Marxian theory has thought of ideology as distorting some real set of relations in such a way that it conceals what is really going on. For Marx, the critique of ideology was at the same time a critique of exploitation embedded in the actual practices of "equivalence exchange." Althusser's formulation restates this critique. But the representations that we have studied wander back and forth between referencing something akin to the real, and constructing imaginary landscapes, not simply imaginary subject relations. Our current research emphatically affirms Baudrillard's thesis, as restated by Smith (2001:3), that “...in the topos of simulacra, any distinction between the represented image and reality vanishes as the historical contexts in which images were reproduced are effaced by their (re)production and circulation." But the conclusion that is drawn from this, that "finally all determinate processes are overthrown and recuperated by the indeterminacy of the late-capitalist code," is much dicier, an ahistorical argument that cannot be empirically verified. Further, it may be - at least in the sphere of capitalist advertising - that the "code" is not quite so unified, but is itself characterized by unevenness and contradiction.

Do the advertising landscapes we have examined constitute a simulacrum of an epoch in which such representations radically eclipse the principle of referentiality? As many times as we have pored through these several thousand advertising texts, we are unable to cleanly disentangle what Jean Baudrillard delineates as the "successive phases of the image" in the present representational moment. Baudrillard's "successive phases of the image," from representation to its negation in simulation are as follows:

1) It is the reflection of a basic reality.

2) It masks and perverts a basic reality.

3) It masks the absence of a basic reality.

4) It bears no relation to any reality whatever: it is its own pure simulacrum. (Baudrillard 1994: 11).

Our examination of corporate advertising texts suggests that these "successive phases of the image" are not historically mutually exclusive. Elements of each phase of the image can be found mashed together in the current historical moment - sometimes within the same advertising text. Baudrillard's phases of the images are less historical stages than ideal types that help us think through the relationship between modes of representation and modes 
of production. Just as there has never been a moment in which the representation has been based on an exact equivalence of "the sign and the real," conversely there is no "pure simulacrum." Rather, a dialectical history of representation can be found recapitulated and negated in the present historical moment.

Whereas consumer-goods ads have become enmeshed in a metacommunicative winking about artifice that prompts some degree of reflexivity about what constitutes the "real" in ad-land, corporate ads adopt a range of metacommunication strategies that are more serious in tone. Hence, whereas consumer ads can be read as locating the "real" neither in the text itself, nor in some external reality, but in the matrix of desire that constitutes the individual subject, corporate ads still seek to locate the "real" in an external reality, albeit a referential world that has been effectively occluded by the over-mediated codes that now stand between us and the more and more fuzzy referents of science, markets, and the social relations of production. Once again we are reminded that there may be a reason for the recurring use of fuzzy, blurry signification strategies - they refer to a world out there that we mostly "know" of via the media frames themselves. As such the "real" world is thus more and more distant from our capacity to conceptually map it with precision (see Goldman, Papson, \& Kersey 2004).

This leaves us to rethink the relationship between political economy and ideology as it is refracted through an apparatus of the simulacrum. It is not that political economy is dead, but rather that there may no longer be a decisive correspondence between historically situated modes of production and modes of representation. Though there are good reasons for locating a transition to the "postmodern" moment in the mechanical reproduction of images, it may be that the either/or of modernism versus postmodernism has exhausted its utility as a trope. In this study we have repeatedly paused to reflect on the apparently postmodern character of the signification processes, while the product of these processes bears a ghostly, albeit emaciated, resemblance to the grand narratives that are often associated with the bourgeoisie's account of modernity.

\section{Endnotes}

1. The exception to this was the UPS campaign of 20022003 that focused separate ads on the office manager, the logistics manager, the shipping manager, the CFO, and the CEO.

2. It should be noted that Morgan Stanley had been accused of employment discrimination by Allison Schieffelin (who had been employed by Morgan Stanley from 1986 to 2000). The case was filed with the Equal Opportunity Employment Commission in 1998 and in 2001, the EEOC "determined that there is reasonable cause to believe that [Morgan Stanley] discriminated against [Ms. Schieffelin] and a class of similarly situated females..." The EEOC filed an additional complaint against Morgan Stanley in Federal Court, alleging "unlawful employment practices" against these women officers and retaliation in the work place against the plaintiff. The EEOC filing alleged that "Morgan Stanley systematically denied opportunities for equal compensation and advancement to a class of professional women." Just prior to trial in 2004, Morgan Stanley settled the sex discrimination lawsuit for \$54 million with the usual language that they were not admitting to the allegations. (See http://www. forbes.com/2002/10/24/cx_aw_1024fine.html and http://www.forbes.com/work/careers/2004/07/07/ cx_da_0707topnews.html)

3. In keeping with the transnational structure of corporate capitalism, information technology investments have accelerated worldwide, though these investments remained disproportionately greater in the United States, which in 1995 accounted for some 40 percent of global information technology consumption (Daniel Schiller 1999: 16).

4. "Help Wanted: The IT Workforce Gap at the Dawn of a New Century," Information Technology Association of America, 1997: 9.

5. All ads that promote the panoptic potential of new technologies structure their narratives around humor.

6. The small print that appears at the end of the ad, reads: "American Express will donate up to \$5,000,000 to Share Our Strength based on three cents per Card purchase. Donations are not tax-deductible by Cardmembers." 


\section{References}

Anderson, Sara and John Cavanagh. 2000. Field Guide to the Global Economy. New York: The New Press.

Althusser, Louis. 1971. Lenin and Philosophy. Translated by Ben Brewster. London: New Left Books.

Augé, Marc. 1992. Non-Places: Introduction to an Anthropology of Supermodernity. London: Verso.

Baudrillard, Jean. 1993. Symbolic Exchange \& Death. Translated by Iain Hamilton Grant. London: Sage.

----. 1994. Simulacra and simulation. Translated by Sheila Faria Glaser. Ann Arbor: University of Michigan Press.

Bauman, Zygmunt. 1999. Liquid Modernity. Cambridge: Polity Press.

----. 1998. Globalization. NY: Columbia University Press.

Bourdieu, Pierre. 1984. Distinction: A Social Critique of the Judgment of Taste. Cambridge: Harvard University Press.

Castells, Manuel. 2000. The Rise of the Network Society. Oxford: Blackwell Publishers.

Castells, Manuel. 2001. The Internet Galaxy. Oxford: Oxford University Press.

Deleuze, Gilles and Guattari, Felix. 1987. A Thousand Plateaus: Capitalism and Schizophrenia. Translated by Brian Massumi. Minneapolis: University of Minnesota Press.

Florida, Richard. 2002. The Rise of the Creative Class. NY: Basic Books.

Friedman, Thomas L. 1999. The Lexus and the Olive Tree. NY: Farrar Straus \& Giroux.

Gold, John R. and Revill, George. 2003. 'Exploring Landscapes of Fear': Marginality, Spectacle. and Surveillance.” Capital and Class, 80: 27-50.

Goldman, Robert and Papson, Stephen. 1996. Sign Wars: The Cluttered Landscapes of Advertising. NY: Guilford.

Goldman, Robert, Papson, Stephen and Kersey, Noah. 2004. "Speed: Through, Across \& In - the Landscapes of Capital," Fast Capitalism, 1:1, www.fastcapitalism.com.
Harvey, David. 1989. The Condition of Postmodernity. Cambridge, MA: Basil Blackwell

"Help Wanted: The IT Workforce Gap at the Dawn of a New Century," Information Technology Association of America, Arlington, VA, 1997, p. 9.

Hochschild, Arlie. 1997. The Time Bind: When Work Becomes Home and Home Becomes Work. NY: Henry Holt \& Co.

Ackman, Dan. "Morgan Stanley and the Women," http://www. forbes.com/work/careers/2004/07/07/cx_da_0707topnews. html. Accessed May 1, 2006,

Weinberg, Ari. “Wall Street Fine Tracker," http://www.forbes. com/2002/10/24/cx_aw_1024fine.html. Accessed May 1, 2006.

Marchand, Roland. 1985. Advertising the American Dream. Berkeley: University of California Press.

Marx, Karl. [1847] 1978. “The Communist Manifesto," pp.473483 in The Marx-Engels Reader, ed. Richard Tucker. NY: Norton.

Marx, Karl. [1849] 1978. "Wage Labor and capital," pp.203-217 in The Marx-Engels Reader ed. Richard Tucker. NY: Norton.

"Measuring Global Poverty," Infoplease. http://www.infoplease. com/ipa/A0908762.html. Accessed February 20, 2006.

Salerno, Roger A. 2003. Landscapes of Abandonment: Capitalism, Modernity, and Estrangement. Albany: State University of New York Press.

Schor, Juliet. 1993. The Overworked American: the Unexpected Decline of Leisure. NY: Basic Books.

Sennett, Richard. 1999. The Corrosion of Character. NY: Norton. Schiller, Dan. 1999. Digital Capitalism: Networking the Global Market System. Cambridge, Mass.: MIT Press.

Smith, Michael W. 2001. Reading Simulacra: Fatal Theories for Postmodernity. Albany: State University of New York Press.

Williamson, Judith. 1978. Decoding Advertisements. London: Marion Boyars. 